\title{
Archaean basin margin geology and crustal evolution: an East Pilbara traverse
}

\author{
Wouter Nijman $^{1 *}$, Armelle Kloppenburg² \& Sjoukje T. de Vries ${ }^{1}$ \\ ${ }^{1}$ Department of Earth Sciences, Faculty of Geosciences, Utrecht University, PO Box 80115, 3508 TC Utrecht, the Netherlands \\ 2 4DGeo Structural Geology, Daal en Bergselaan 80, 2565 AH The Hague, the Netherlands \\ *Correspondence: w.nijman@uu.nl
}

\begin{abstract}
A palinspastic reconstruction of a $100 \mathrm{~km}$ long traverse through Archaean rocks of the East Pilbara, Western Australia, includes new observations of the deformation preceding the now visible greenstone belt pattern. The restoration is time-calibrated with all available $\mathrm{U}-\mathrm{Pb}$ datings.

Between incompletely preserved basin sequences, two superposed Palaeoarchaean volcano-sedimentary basins (the Coongan and Salgash Basins) are separated by an eastwards time-transgressive interface tentatively interpreted as an onlap surface. For over $140 \mathrm{Ma}$, the basin margin architecture was structurally controlled by superposed extensional growth fault arrays $\left(D_{1}\right)$ with associated dyke swarms in a curved pattern spatially not related to that of the actual distribution of granite domes and greenstone belts.

The basins are interpreted to have formed by collapse after arching above hotspots due to phase transitions by mini-subduction of slabs of cooled water-saturated basalt towards the base of an originally $c .45 \mathrm{~km}$ mafic crust. At c. $3.31 \mathrm{Ga}$, the extension was replaced by plate-driven regional NW-SE compression $\left(\mathrm{D}_{2}\right)$ inferred from NW-over-SE shear and ramp-and-flat thrusts, partly reversing offsets of the $\mathrm{D}_{1}$ extension. The recognition of widespread $\mathrm{D}_{2}$ pre-doming compression is important because it triggered the $c .3 .18 \mathrm{Ga}$ start of formation of the dome-and-keel pattern $\left(\mathrm{D}_{3}\right)$ visible today, which culminated at c. $2.9 \mathrm{Ga}$.
\end{abstract}

Supplementary material: Eight figures, numbered 'Supplementary material fig. a-h', and a GPS list of observation sites are available at: https://doi.org/10.6084/m9.figshare.c.3808243

Received 28 September 2016; revised 19 April 2017; accepted 21 April 2017

Throughout the last three decades of research on the Archaean, the old intriguing questions about the nature of the early Earth's crust, its rigidity and thickness, the style of its structural development and the balance between vertical diapirism (Hamilton 1998) and tangential plate motion (De Wit 1998) played, and still play, an important role (e.g. Blewett 2002; McCall 2003; Hickman 2004; Van Kranendonk et al. 2004, 2007; Van Kranendonk 2010a; De Wit et al. 2011; Van Hunen \& Moyen 2012; Gerya 2016).

Concurrent with the extensive 1:100 000 mapping project of the Geological Survey of Western Australia (GSWA) in the Archaean Pilbara Craton of NW Australia (for summaries see Hickman 2012a; Hickman \& Van Kranendonk 2012), Utrecht University (the Netherlands) was running a project with a twofold approach: one group working from originally deeper crustal levels of metamorphic and highly deformed rocks upwards, the other from uppermost crustal and less metamorphic rocks downwards, in order to meet in conclusions about the structural development of the craton. Mapping at a range of scales, including detailed (c. 1:10 000) mapping of relatively small key areas (Figs 1 and 2), was combined with geochronological efforts to determine the larger-scale absolute time relationships. The work related to the Pilbara was published in PhD theses ${ }^{1}$ (Zegers 1996; Beintema 2003; Kloppenburg 2003; De Vries 2004; Strik 2004; Van den Boorn 2008) and in articles (see further references in this paper).

With respect to the Palaeoarchaean, important questions to be tackled were: what could be learned about the crustal structural development and the driving force behind it from sedimentological characteristics such as basin shape and fill? From a sedimentological perspective specifically: are we, or are we not, dealing with

${ }^{1}$ Publications of the Utrecht Pilbara project are indicated with * in the list of references. important facies changes and, if so, are these driven by the crustal structural development? An early example of such an approach related to our study area can be found in DiMarco \& Lowe (1989). In Utrecht University's project the emphasis was on the relationship between sedimentation and structural control, both in the Pilbara and the South African Barberton Greenstone Belt, a relationship for the Palaeoarchaean $(3.6-3.2 \mathrm{Ga})$ that turned out to be difficult to compare with Phanerozoic settings. For the Mesoarchaean $(3.2-2.8 \mathrm{Ga})$, on the contrary, the influx of the first large volumes of coarse-clastic arkosic sandstones, both in the Pilbara and in Barberton (Zegers et al. 1998), heralded the facies assemblage familiar to Phanerozoic orogens related to plate motion.

At present, opinions diverge on the timing of the successive deformation phases with respect to the onset of greenstone belt formation, the latter since Collins et al. (1998) generally related to a process of crustal convective overturn. Here, we distinguish three successive phases of deformation: $\mathrm{D}_{1}$ extension, $\mathrm{D}_{2}$ compression and $\mathrm{D}_{3}$ related to steepening of the greenstone sequence and geomorphological 'belt' development. The term 'phase' should be understood as an - in comparison to the Phanerozoic - long-lasting episode of uniform, though possibly pulsating, structural regime.

The evident and high demand for geochronological data in these studies of Archaean rock resulted in a wealth of SHRIMP and Argon datings. Notwithstanding the density of the sampling and the relative accuracy and precision of the age determination, the methods are still insufficient to assess, for instance, continuity or discontinuity within the stratigraphic column. Therefore, it is an obvious pitfall to oversimplify stratigraphic correlations and overlook lateral variations in stratigraphy.

We present a synthesis of our bottom-up and top-down approaches, aiming to identify relationships between structural development and sedimentary response. To that end we revisited East Pilbara and 
compiled a $c .100 \mathrm{~km}$ long east-west traverse through the craton (Fig. 2; location map in Fig. 1). It extends from Bamboo Creek through the Coppin Gap and Marble Bar belts westwards over the North Pole Dome to just beyond the Mulgandinnah Fault zone. The traverse integrates data from previous publications with new observations from key locations along the traverse (Fig. 2, sites 122; see GPS list of the locations in the Supplementary material).

The traverse combines well-preserved Palaeo- and Mesoarchaean structural, sedimentological and volcanological features with a relatively good time control from $\mathrm{U}-\mathrm{Pb}$ datings (Figs 2 and $3 \mathrm{~b}$ ). A stepwise palinspastic reconstruction of the traverse (Fig. $3 a \rightarrow b \rightarrow c$; legend in Fig. 1) allows for an interpretation of the basin configuration and concurrent lateral facies changes. In combination with interpretations of structures that formed at originally deeper crustal levels, we arrive at a model of structural evolution of the Archaean crust of the Pilbara, which in several aspects differs from the protocontinental model proposed by Van Kranendonk et al. (2015a).

\section{The East Pilbara traverse observed}

\section{Corridor map and construction of the traverse}

\section{Corridor map and traverse}

Primary sources for the corridor map (Fig. 2) and the cross-section (Fig. 3a) are:

(1) the new 1:100 000 GWSA geological map sheets: North Shaw (2nd edn, Hickman 2012b; explanatory note by Van Kranendonk 2000), Marble Bar (Hickman \& Van Kranendonk 2008), Coongan (Van Kranendonk 2004; explanatory note by Van Kranendonk 2010b), Muccan (Williams 1998; explanatory note by Williams 1999) and Mt Edgar (map and explanatory note by Williams \& Bagas $2007 a, b)$; notice that these map sheets will be further mentioned in the text without references;

(2) new field observations, air photo and satellite image interpretation;

(3) observations and measurements made previously in our own project: the Dresser Fm in the North Pole Dome (Nijman et al. 1998/99a and in Van Kranendonk et al. 2001a); the northern Marble Bar Greenstone Belt (Coppin Gap Belt) (Nijman et al. 1998/99b and in Van Kranendonk et al. 2001a; De Vries 2004; De Vries et al. 2006, 2010; unpublished MSc maps of the Bamboo Creek Gold Mine area, the Razorback area, and the Kittys Gap volcanosedimentary complex; ${ }^{2}$

(4) the Mount Edgar granitoid complex and the western Marble Bar Belt (Beintema 2003; Kloppenburg 2003).

The corridor map (Fig. 2) and traverse (Fig. 3) are subdivided into five sectors, from east to west:

(1) the Bamboo Creek Sector, corresponding to the northeastern part of the Marble Bar Greenstone Belt ${ }^{3}$ which encircles the granitoid Mount Edgar Dome;

(2) the Coppin Gap Sector for the parts of the Doolena Gap and Marble Bar greenstone belts between the Mount Edgar and Muccan domes that, respectively, represent the northern and southern limbs of the Coppin Gap Syncline. The Gorge Range comprises the westward

${ }^{2}$ We apply the concept of volcano-sedimentary complexes (for instance the Kittys Gap volcano-sedimentary complex) to denote closely interrelated bimodal mafic-felsic volcanic/sedimentary chert complexes often affected by normal growth faulting (cf. Nijman \& De Vries 2004; De Vries et al. 2010).

${ }^{3}$ Greenstone belt nomenclature, as far as applied in the text, according to GSWA (Hickman 2011). continuation of the Doolena Gap Greenstone Belt over the Talga Talga River along the south side of the Muccan Dome.

(3) the Marble Bar Sector, the north-striking, western part of the Marble Bar Greenstone Belt;

(4) the Glen Herring Synclinorium (new name after Glen Herring Creek); and

(5) the North Pole Dome (further abbreviated as NP Dome). To avoid unnecessary complexity in the description, the name 'Panorama Greenstone Belt' for the greenstone cover of the NP Dome will not be used.

\section{Remarks on the stratigraphical correlation}

The legend (Fig. 1) of the corridor map presents the dated stratigraphical sequence used in this paper. The following correlations differ from those made in the GSWA maps:

North Pole, McPhee and Razorback Cherts: the Razorback Chert of the Coppin Gap Sector (just south of site 11 in Fig. 2) is correlated here with the McPhee Chert in the Marble Bar Sector (sites 12-15) and the North Pole Chert (Dresser Fm) in the NP Dome (site 20). As a consequence, the underlying sequence of the Razorback Chert is designated to the Talga Talga Subgroup (De Vries et al. 2006; cf. section 'Razorback Chert and Shear Zone' below).

Mount Ada Basalt, Apex Fm and the Antarctic Creek Member: in the NP Dome the top of the Mt Ada Basalt is placed at the contact with the, in places discontinuous, felsic volcanic/chert unit known as the Antarctic Creek Member (stratigraphic level of sites 10c and 22) of the Mt Ada Basalt (Australian Stratigraphic Units Data Base). The age of the Antarctic Creek Member $\left({ }^{207} \mathrm{~Pb} /{ }^{206} \mathrm{~Pb}\right.$ age of 3470.1 $\pm 1.9 \mathrm{Ma}$, Byerly et al. 2002) corresponds with that of the lower part of the Duffer Fm further to the east in the Bamboo Creek Sector. We consider the felsic volcanic component of the member as a pinchout of the Duffer Fm between the Mt Ada Fm and the next younger basalt unit, the Apex Fm. La-ICP-MS ${ }^{207} \mathrm{~Pb} /{ }^{206} \mathrm{~Pb}$ datings of 3454 $\pm 46,3463 \pm 34$ and $3465 \pm 18 \mathrm{Ma}$ from the Antarctic Creek Member by Kitajima et al. (2008) are consistent with this correlation. In placing the boundary between the Mt Ada and Apex Fms at this stratigraphic interval, we apply the stratigraphic subdivision of the NP Dome in the first edition of the North Shaw 1:100 000 geological map (Van Kranendonk 1999). We do not follow the correlation in the second edition of that map (Hickman 2012b), in which the top of the Mt Ada Basalt has been moved stratigraphically way upwards, bringing the Duffer Fm in direct contact with the Panorama Fm (see below and the section 'Salgash Basin margin') at the complete expense of the Apex Fm.

The chert beds and other clastic intervals of the Antarctic Creek Member in the NP Dome and elsewhere in the lower part of the Apex Fm, previously named Towers Formation (Hickman 1977; Van Kranendonk et al. 2006), can be correlated over the entire length of the traverse (hatching in colour legend of the Apex Fm in Figs 2 and 3), providing a reliable lithostratigraphic correlation for the base of the Apex Fm.

The (pillow-) basalts between the Duffer Fm and the so-defined base of the Apex Fm in the Bamboo Creek Sector are included in the Mt Ada Basalt. Likewise, tongues and lenses of basalt observed within the Duffer Fm in the Coppin Gap Sector are here interpreted as the lateral, interdigitating contact between the two formations.

Panorama Fm and overlying cherts: The Apex Fm is overlain by felsic volcanic and volcaniclastic rocks of the Panorama Fm. Ages of the latter range from 3458 to $3434 \mathrm{Ma}$. We consider the entire felsic volcano-sedimentary unit exposed along the southern rim of the NP Dome as Panorama Fm (site 18 in Fig. 1), instead of a superposition of the Duffer Fm by the Panorama Fm in the local 


\section{LEGEND to figures 2 and 3}

\section{Stratigraphy}

Sediments

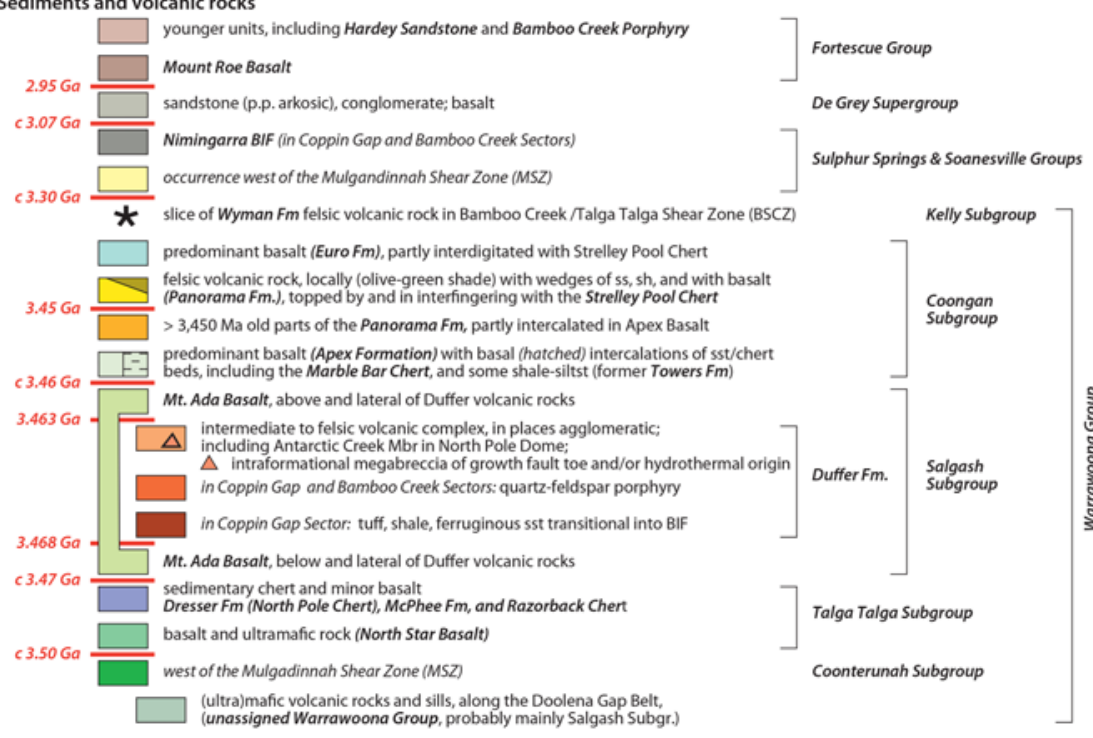

Intrusive rocks
$\square$ granitoid complexes
$\square \quad$ south Muccan Shear Zone (SMSZ)
$\square 2.8$ Ga dolerite dykes

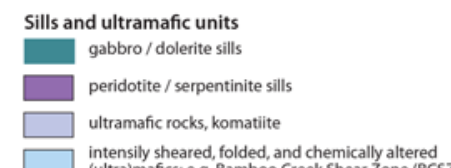

Unconformities (for Figure 3 only) Unconformities (for figure 3 -..- base Fortescue Group ....... base De Gery Supergroup

...... base Nimingarra

Ine. intra Warrawoona Group (local)

\section{Structures}

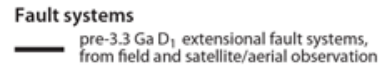

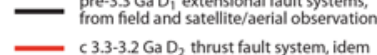

c 3.3-3.2. $\mathrm{Ga}_{2}$ thrust fault system
$\mathrm{D}_{2}$-reactivated $\mathrm{D}_{1}$-faults, idem

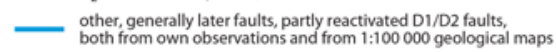

:Z:: $D_{1} / D_{2}$ faults interpreted from existing $1: 100000$ geological maps

\section{Folds (for Figure 3 only)}

$\vec{P}$ bulk shear (from folds and foliations)

$\checkmark D_{1}$ folds with vergence within plane of section

$\Omega D$, folds with vergence at high angles to plane of section

* synforms

Other (for Figure 3 only)

$\nabla$ thickness control points in fig. 3c

$\checkmark$ thickness con

\section{Stereoplots (for Figure 2 only)} (data from Zegers 1996: fig. 7.5 )

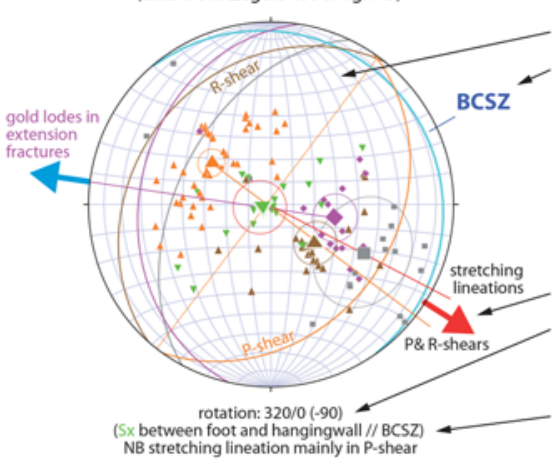

\section{Geochronology (in Figure 2)}

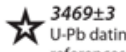

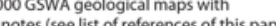

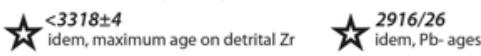

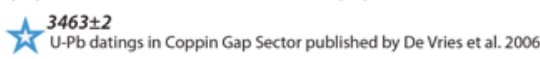

by 2916/26

\section{Location map}

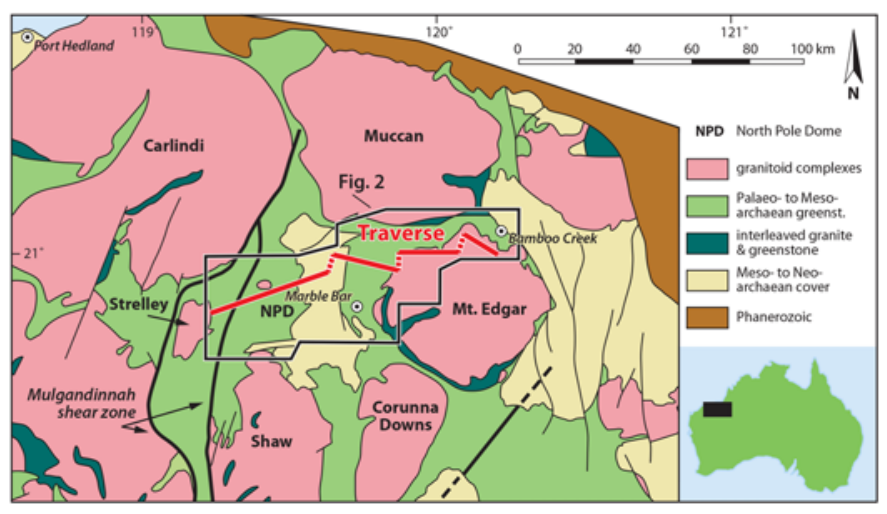

Fig. 1. Legend to Figures 2 and 3, with stratigraphic column, structural and geochronological features and reference map.

light blue great circle: major shear zone, Bamboo Creek Sz

So (black): bedding; So" (brown): displaced by thrusting,

$S_{1}$ and $S_{2}: D_{1}$ and $D_{2}$ folliation, in general fracture cleavage

Sx unassigned foliation

back-rotated mean vergence : blue: $D_{1}$; red $D_{2}$

information about rotation procedure:

\section{ting or late fauting}

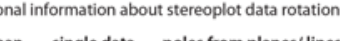

nean single data poles from

- $\quad$ bedding disturbed by $\mathrm{D}_{1}$ or $\mathrm{D}_{2}\left(5 \mathrm{~S}^{\circ}\right)$

- foliation $S_{1}$

- $\quad \begin{aligned} & \text { foliation } \mathrm{S}_{2} \text { or } 5 \mathrm{x} \\ & \text { faut planes } \sim \text { red great circles }\end{aligned}$

- $\quad D_{1}$ fold axes

$4 \quad$ P.shears $\sim$ orange great circles

R-shears $\sim$ brown great circles

principal displacement shears
lineations, mostly stretching
extension veins, tension gashes 
Traverse North Pole Dome-Bamboo Creek

Corridor map with localities, stereoplots and datings

_ trace of traverse

- observations sites for stereoplots

russ:1 $_{3 \text {, datings }}$

detailed mapping areas

$\square$ text figures

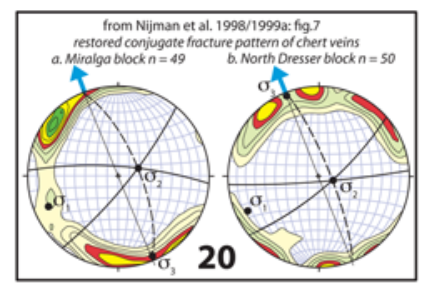

10

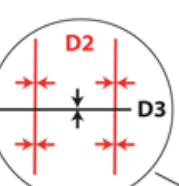

8
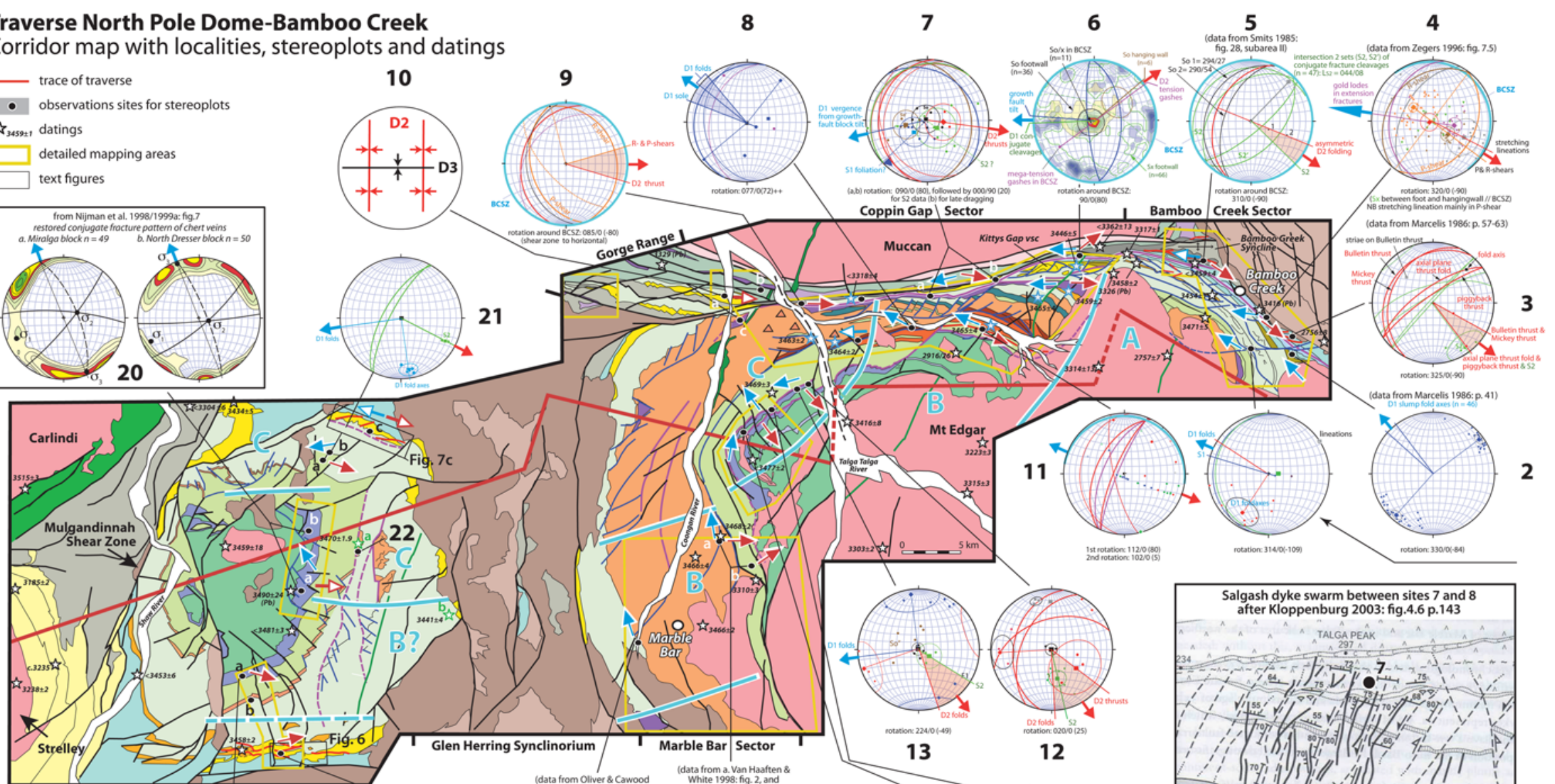

\%
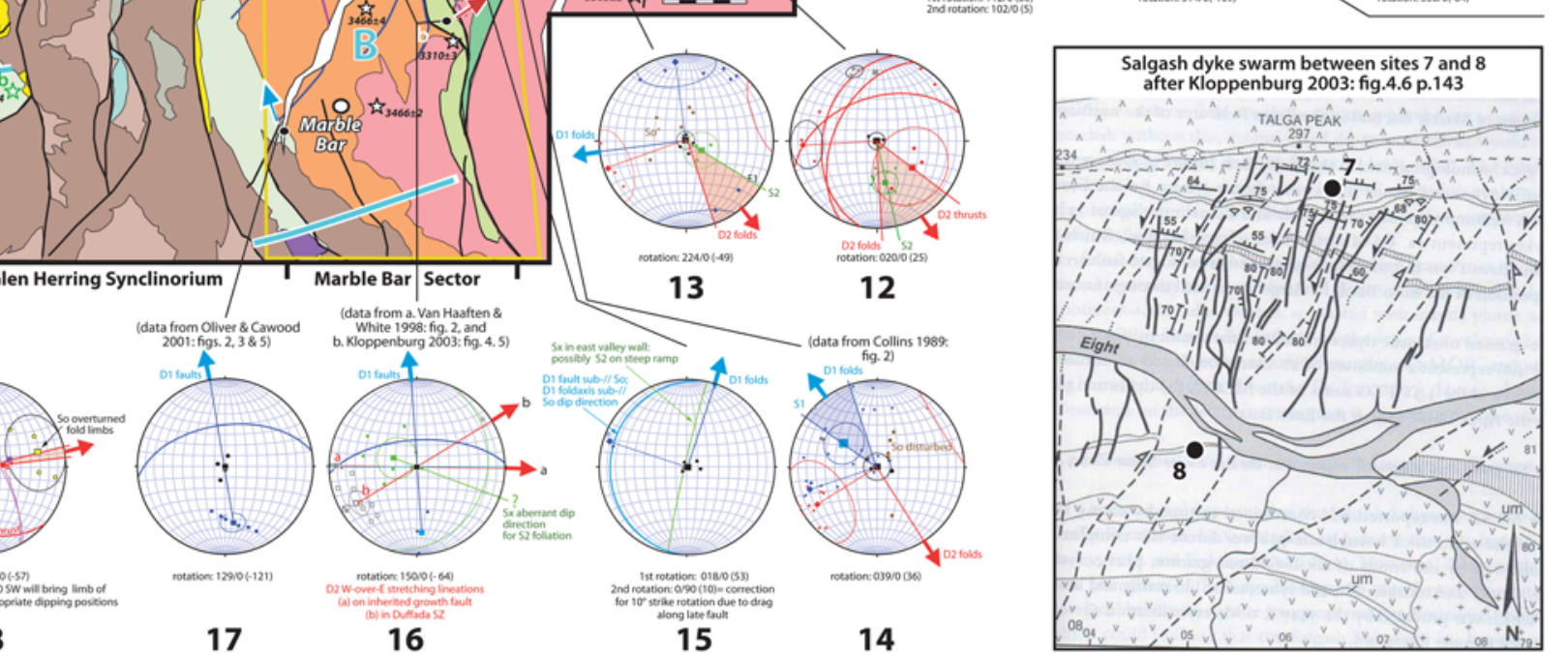

14
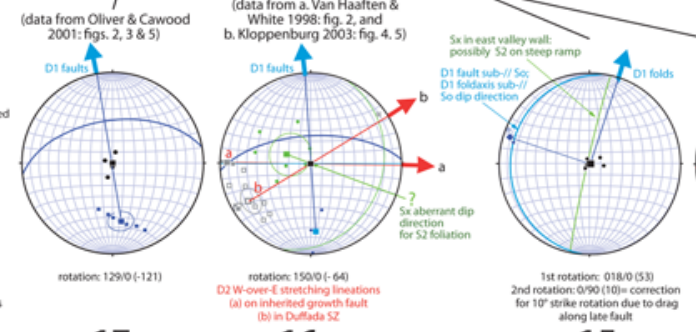

12
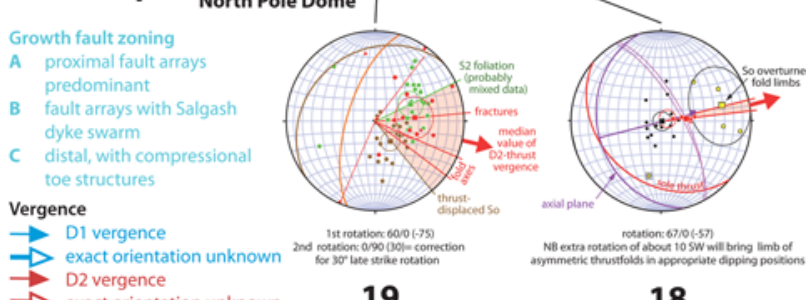

17

16

15

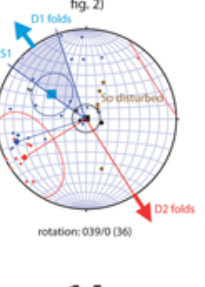

Fig. 2. Corridor map of the East Pilbara traverse (reference map in Fig. 1). Trace of the traverse of Figure 3 in red. Observation sites, numbered $1-22$, with back-rotated structural vergences, indicated in blue $\left(D_{1}\right)$ and red $\left(D_{2}\right)$

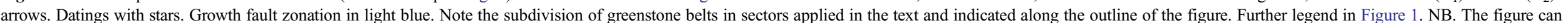
be enlarged in the online edition of the article. (See Supplementary material fig. a for a high resolution version of the stereoplots.) 
absence of the Apex Basalt (see above). Datings of $3458 \pm 2 \mathrm{Ma}^{4}$ (Thorpe et al. 1992) in the lower part of the formation along the south flank of the NP Dome and of $3453 \pm 6$ Ma more westwards along the Shaw River (GSWA sample 160958 with maximum age: Wingate et al. 2011) correspond well with the $3454 \pm 1 \mathrm{Ma}$ (GSWA sample 94770, Thorpe et al. 1992) for a felsic volcanic intercalation of Panorama Fm affinity in the upper part of the Apex Fm, south of Coppin Gap in the Bamboo Creek Sector. The latter dating, on the one hand, was re-assessed by Amelin et al. (2000) at $3448 \pm 2 \mathrm{Ma}$, but, on the other hand, it is accompanied by one of $3458 \pm 2$ Ma for the same stratigraphic level (Williams 1999: GSWA sample 100511, Thorpe, pers. comm. 1991). It points to a maximum age of the Panorama Fm of c. $3456 \mathrm{Ma}$ in the western part of the traverse and of c. $3450 \mathrm{Ma}$ in the east. In the nearby eastern part of the Coppin Gap Sector an andesitic layer with affinity to the underlying Duffer Fm in the lower part of the Apex Fm (former Towers Fm) has been dated at $3459 \pm 2 \mathrm{Ma}$ (De Vries et al. 2006). The above datings combined illustrate the transition from the largely intermediate Duffer volcanic regime into the exclusively felsic one of the Panorama Fm during deposition of the Apex Formation.

Everywhere along the traverse east of the Mulgandinnah SZ, the Panorama Fm is capped by one or more chert layers interlayered with basalt, a stratigraphic unit known as the Strelley Pool Chert (Lowe 1983) or, further eastwards, also as the Kittys Gap Chert (Nijman et al. 1998/99b). We consider this - in places, interdigitating - contact as a conformity (Van Kranendonk et al. 2001a; De Vries et al. 2010), not as a regional unconformity (Hickman 2008). Nevertheless, minor local unconformities can be expected to have resulted from $\mathrm{D}_{1}$ synsedimentary deformation, as will be shown below. To the west of the Mulgandinnah Shear Zone, on the contrary, a major unconformity along the base of the Strelley Formation has been established (Buick et al. 1995).

Below we will argue that the Panorama Fm and the overlying Strelley Pool cherts are composed of one or more - and then laterally linked - diachronous volcano-sedimentary complexes.

Panorama v. Duffer Fm in the Gorge Range: The Gorge Range is interpreted differently than in the Coongan 1: 100000 sheet. We observed range-parallel, tight, horizontal to gently inclined upright folds, affecting both the upper part of the Warrawoona Group and the unconformably overlying clastic suites of the De Grey Supergroup (Fig. 3, and Nijman et al. 1998/99b). The relatively thick silicified sandstones overlying felsic volcanic rocks at Doolena Gap are not regarded as an unconformable superposition of Strelley Fm upon Duffer volcanic rocks, as indicated in the Coongan 1:100 000 sheet (Van Kranendonk 2010b; cf. Wiemer et al. 2016), but as a volcano-sedimentary complex (designated 'P'assemblage in Nijman et al. 1998/99b) with lateral transitions of Panorama and Strelley Pool Fms comparable to what has been observed in the Kittys Gap volcano-sedimentary complex further eastwards (De Vries et al. 2010; cf. the section 'The Salgash Basin margin' below).

Nimingarra BIF and the base of the De Grey Supergroup: In the Coppin Gap Sector, an important banded iron formation has been mapped as the Nimingarra Iron Fm (Gorge Creek Group, i.e. part of the De Grey Supergroup) in the Muccan 1:100 000 sheet and as the Paddy Market Formation (part of the Soanesville Group) in the Coongan 1:100 000 sheet. The Nimingarra BIF (name used in this paper) is bounded by two important unconformities. It rests unconformably on Euro Basalt and is itself unconformably overlain

${ }^{4}$ In the $\mathrm{Zr}$ geochronology of the NP Dome by Kitajima et al. (2008) an - in comparison with the existing data - anomalous dating of $3660 \pm 52 \mathrm{Ma}$ of a rhyolite in the Panorama Fm along the south flank of the dome forms the main argument for a farreaching conclusion on crustal growth by stacking of upwards increasingly older thrust slices. Recently this model, in our view based on insufficient evidence, re-appeared in Kusky et al. (2016). by De Grey Supergroup clastic sediments and basalts. Along the northern limb of the Bamboo Creek Syncline (Fig. 2 and Supplementary material fig. b; also known as Coppin Gap Syncline) lenses of quartz-arenite are associated with the Nimingarra BIF; one of these, along its base, provided a detrital zircons maximum age of $3362 \pm 13 \mathrm{Ma}$ (Nelson 1998). Along the southern limb the unconformity at the top of the Nimingarra BIF shows pronounced palaeorelief and angularity, covered by uplapping coarse conglomerates and basalt of the De Grey Supergroup. The Bamboo Creek Syncline represents the synform of the greenstone belt between the Mount Edgar and Muccan granitoid complexes (Fig. 2). Progressive unconformities in the uplap sequence filling the core of the syncline demonstrate its synsedimentary growth. It indicates that the steepening of the greenstone belt, i.e. the forming of the keel, occurred during deposition of the De Grey Supergroup (Nijman et al. 1998/99b, fig.12; upgrade in Supplementary material fig. b).

We therefore agree with Van Kranendonk's (2004, 2010b) assignment of the Nimingarra BIF (as Paddy Market Fm) to the iron-rich Soanesville Group (3200-3180 Ma, Hickman 2012a), west of the Mulgandinnah Fault Zone (Figs 2 and 3a). A c. $3.19 \mathrm{Ga}$ age $^{5}$ for the Nimingarra BIF is nevertheless considerably younger than the above-mentioned detrital $\mathrm{Zr}$ age of $<3362 \mathrm{Ma}$. The Nimingarra BIF is the youngest stratigraphic unit participating in the $\mathrm{D}_{2}$ phase discussed in this paper (cf. section 'The traverse during 3.3 - 3.2 Ga compression $\mathrm{D}_{2}$ ').

\section{Reconstruction of palaeogeometries using stereographic projections}

The orientations of folds, faults and associated foliations are combined with shear sense indicators and stretching lineations where available. Orientations and kinematics are analysed and presented per observation site in stereoplots (OsXStereonet: Allmendinger et al. 2012; Cardozo \& Allmendinger 2013; Figs 1 and 2 and Supplementary material fig. a). The amount of data per site is variable. Some plots are based on tens of measurements, but more often the observations to detect geometries and vergences of faults and folds consist of a mix of macro- and meso-scale measurements. To gain insight into the style and amount of predoming deformation, in particular synsedimentary effects, we applied rotation of the data back into their original position:

(1) structures recognized as syn-depositional, such as growth faults and slumps, or truncated by an unconformity, were restored to their pre-tilted orientation for kinematic interpretation (cf. the section 'Pre- to syndoming character of $\mathrm{D}_{2}$ compression');

(2) the effect of doming and greenstone belt tilt was restored at each individual locality by rotation on the local bedding strike.

\section{Bamboo Creek and Coppin Gap sectors}

\section{Previous work}

The east-west-trending Marble Bar Greenstone Belt in the Coppin Gap and Bamboo Creek sectors (previously called the Coppin Gap Greenstone Belt) of the traverse has been the subject of several publications of our group (see maps in Nijman et al. 1998/99b; Kloppenburg 2003; De Vries et al. 2006; and in Van Kranendonk

${ }^{5}$ Just before the publication of this paper, Sheppard et al. (2017) published a $3104 \pm$ $16 \mathrm{Ma}$ U-Pb zircon age of a volcanic tuff between two Nimingarra BIF units in the nearby Shay Gap and Goldsworthy belts of the NE Pilbara craton. Although a bit younger, this dating roughly corresponds with our estimate of $3.19 \mathrm{Ga}$ for that formation and results in a comparable conclusion about the stratigraphic position of the Nimingarra BIF 


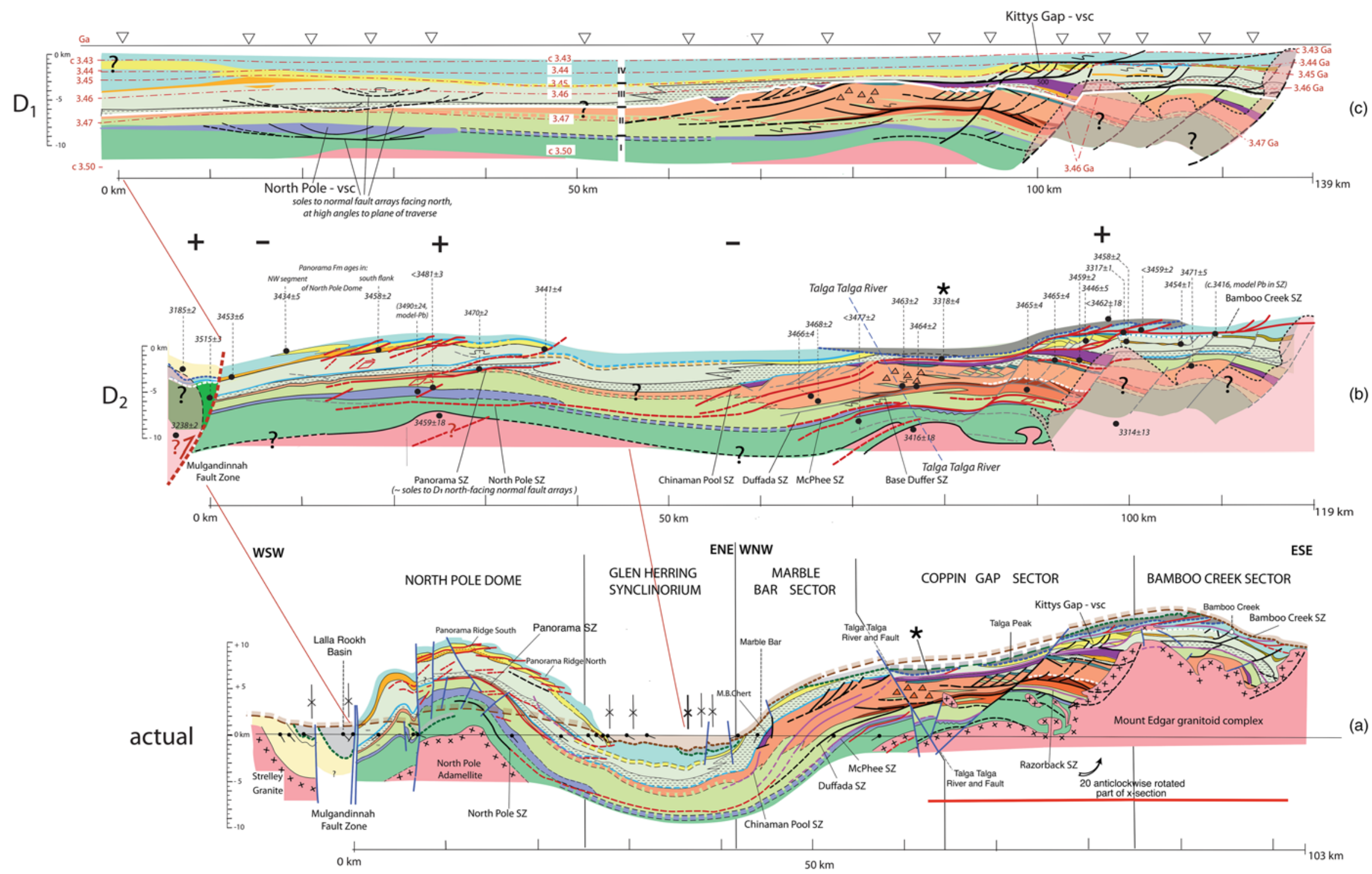

Fig. 3. The East Pilbara traverse along the trace in Figure 2: (a) actual cross-section; (b) the traverse restored for $\mathrm{D}_{3}$ doming, showing the situation at the end of the $\mathrm{D}_{2}$ phase of compression tectonics; (c) the traverse restored for $\mathrm{D}_{3}$ and $\mathrm{D}_{2}$, at the end of synsedimentary $\mathrm{D}_{1}$ normal growth faulting that persisted during deposition of the Warrawoona Group. Legend in Figure 1. 
et al. 2001a). Because of the steep dip to the north the present outcrop of the belt affords an almost perfect cross-section. To fit the section into the traverse with true thicknesses it was merely corrected for the gradual northward steepening from $50^{\circ}$ dip angle at the base of the stratigraphic sequence to vertical dips at the top in the core of the belt's syncline. From the discordant intrusive relationship between greenstone and the Mt Edgar intrusion it is evident that the greenstones of the Coppin Gap and Bamboo Creek sectors formed part of the roof of the southerly adjacent Mt Edgar granitoid complex (Figs 2 and 3a) before they obtained their present steeply dipping attitude.

\section{Bamboo Creek Sector}

One of the major shear zones of the East Pilbara is the north- to NEdipping Bamboo Creek Shear Zone (further abbreviated: SZ). Its structural evolution has been examined extensively: first during an MSc-project focusing on the Bamboo Creek gold mine in the mid$1980 \mathrm{~s}$; later during the research of Zegers (1996) and of the present authors. When the stratification of the host rock as well as the shear zone are restored to horizontal, the pre-doming kinematics of the shear zone can be analysed. The shear zone provides good examples of the overprint of west- to NW-vergent extensional features like foliations, fracturing and (slump)folds $\left(\mathrm{D}_{1}\right)$ by SE-vergent thrust structures $\left(D_{2}\right)$ (stereoplots 3 and 4 in Fig. 2) prior to steepening of the shear zone. The gold mineralization is related to the extension in the shear zone and has been dated at c. $3400 \mathrm{Ma}$ (Zegers et al. 2002; stereoplot 4).

The hanging wall is composed of Euro Basalt, with at least seven intercalated chert layers, and the unconformably overlying Nimingarra BIF. The deformation shows overprinting by $D_{2}$ eastvergent thrusts of previously not recognized irregular to westvergent fold structures in the Euro Basalt (stereoplots 3 and 5, and Supplementary material fig. b).

In the footwall of the Bamboo Creek SZ, silicified pillow basalts of the Euro Fm overly the Apex Basalt. The Panorama Fm is missing (hiatus/non-deposition?), but the style of deformation is the same as in the Panorama rocks of the Kittys Gap volcanosedimentary complex some tens of kilometres westwards: a series of extensional fault blocks terminating eastwards against a leading growth fault. The hanging wall of that leading fault accommodates a wedge of shale and cross-bedded sandstone comparable, though much richer in the sandstone component, to the one described in the Kittys Gap volcano-sedimentary complex (Nijman et al. 1998/99b), and with many slump folds (stereoplot 2).

In the entire sequence of the Warrawoona Group below this stratigraphic level, down to where it includes the volcanic rocks of the Duffer Fm (dated at $3471 \pm 5$ Ma by Thorpe et al. 1992), extensional growth faults are the dominant structural features. Several listric fault arrays (concave to the NW and c. $1-3.5 \mathrm{~km}$ thick) are accompanied by chaotic folding and rollover anticlines (Fig. 2 and Supplementary material fig. c). The fault arrays merge downwards in bedding-parallel detachment zones, one of which is illustrated in detail (Fig. 4: Site 1, and Supplementary material fig. d). It consists of an irregularly and intraformationally folded and sheared basalt between two chert units, $400 \mathrm{~m}$ apart, in the lower part of the Apex Fm, i.e. the former Towers Fm (stereoplot 1). Axial planes vary from parallel to bedding to upright. Northwestwards along-strike, and within the same deformed stratigraphic interval, satellite images show several flexures and asymmetrical folds with NW vergence.

\section{Coppin Gap Sector}

Here, too, a superposition of extensional growth fault arrays of several orders of magnitude is the dominant structure, as already described by De Vries et al. (2006), from which features relevant to this analysis are highlighted below with addition of new information.

Razorback Chert and Shear Zone. The correlation of the thin Razorback Chert (Fig. 2, immediately below the shear zone of site 11) with the much thicker chert of the McPhee Formation is firmly based on the observation of significant dextral dragging and fragmentation of the chert along and within the major SW-NEorientated Box Soak Fault (Figs 2 and 3). The latter fault is a repeatedly reactivated fault, initiated as a west-block down growthfault (prior to steepening of the stratification), which accounts for the dragging. The Mt Ada Basalt overlies the chert but is intensely sheared by the Razorback SZ, similar to - and the correlate of - the McPhee Chert-Mt Ada Basalt contact in the Marble Bar Sector (see below). Stereoplot 11 (Fig. 2) shows a change of kinematics of the shear zone, in an unfolded state, from east-over-west to NW-over$\mathrm{SE}$, inferred from overprinting of $\mathrm{S}_{1}$ by axial planar $\mathrm{S}_{2}$ foliation.

The actual contact between the Razorback SZ and the $3314 \pm$ $13 \mathrm{Ma}$ old Coppin Gap Granodiorite Suite (Figs 2 and 3; Supplementary material fig. e) of the Mount Edgar Dome could not be detected in outcrop. This leaves an uncertainty: is the shear zone with its $\mathrm{D}_{2}$ structures deflected along the contact towards higher stratigraphic levels or is it truncated by the contact? This uncertainty allows for three interpretation scenarios as to the start of the $\mathrm{D}_{2}$ compressional phase (cf. the section 'Pre- to syndoming character of $\mathrm{D}_{2}$ compression').

Deformed BIF along the base of the Duffer Fm. The lower part of the Duffer Fm in the Coppin Gap Sector is composed of a $1200 \mathrm{~m}$ thick qtz-fsp porphyry unit (dated at $3465 \pm 4 \mathrm{Ma}$, De Vries et al. 2006) which is overlain by $160 \mathrm{~m}$ of BIF. Field observations combined with satellite radar image interpretation (Supplementary material fig. e) shows that the ensemble has been low-angle faulted east-over-west and subsequently unconformably covered by intermediate volcanic rocks that form the bulk of the formation. The BIF itself has been internally slump-folded (De Vries et al. 2006, fig. 12; stereoplot 8). Westwards, passing the Talga Talga River, again intraformational low-angle thrusts are found, which merge into a megabreccia within the Duffer Fm (triangles in Figs $1-3$ ). Notice that the east-over-west $\mathrm{D}_{1}$ thrusting is opposite to the NW-over-SE $\mathrm{D}_{2}$ compressional structures. The direct link between the growth faults and west-vergent compressional structures characterizes the $\mathrm{D}_{1}$-extension as a surficial synsedimentary deformation resembling large-scale sliding and slumping.

Further westwards, the deformation of the BIF at the base of the Duffer Fm in the Coppin Gap Sector can be traced into the Duffada SZ of the Marble Bar Sector (cf. section 'Fault patterns in the Coongan and Salgash Subgroups').

The Salgash mafic dyke swarm in the Coppin Gap Sector. Densily spaced vertical dolerite/gabbro/peridotite dykes intruded the Duffer Fm and the overlying Apex Fm in the Coppin Gap Sector (between sites 7 and 8 in Fig. 2). This is the Salgash dyke swarm described by Kloppenburg (2003, fig. 4.6, reproduced as inset of Fig. 2). The dyke swarm is also present across the Marble Bar Sector (cf. section 'The Salgash mafic dyke swarm in the Marble Bar Sector' below). The dykes are considered to be feeders to the mafic units in the Salgash Subgroup and, as such, as direct $D_{1}$ extension indicators in Salgash times.

Bamboo Creek Shear Zone and Kittys Gap volcano-sedimentary complex. For further observations and conclusions with regard to the Coppin Gap Sector, and the Kittys Gap volcano-sedimentary complex in particular, we refer to earlier publications (Nijman et al. 1998/99b; Van Kranendonk et al. 2001a; De Vries 2004; Nijman \& De Vries 2004; De Vries et al. 2006, 2010; Orberger et al. 2006; Westall et al. 2006; Van den Boorn et al. 2007).

In Figure 2, sites 6, 7 and 9 are located along what we interpret to be the continuation of the Bamboo Creek SZ westwards along the Talga Talga Range. Reversal of the translation direction along the 

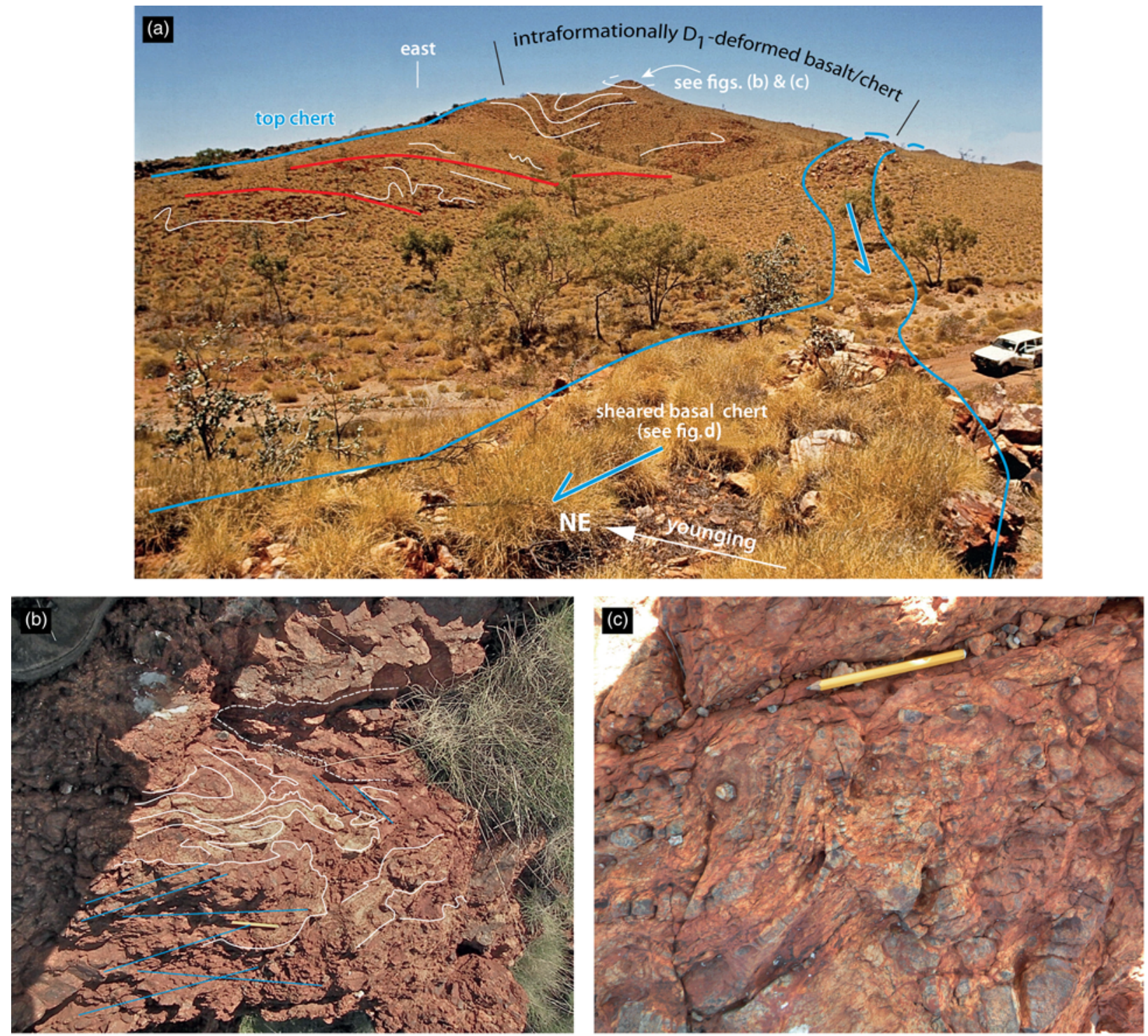

$D_{1}$ plastic/chaotic

\section{(d)}

$D_{1}$ brittle

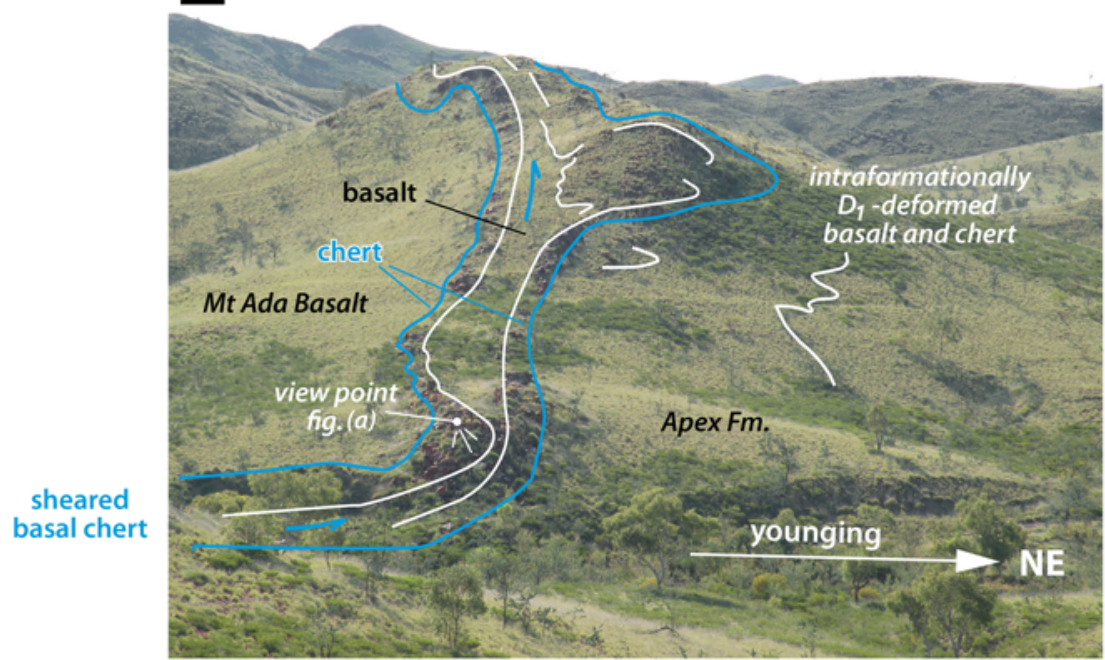

Fig. 4. Bamboo Creek Sector, site 1 (Fig. 2; see also Supplementary material figs c and d). Detachment zone along the base of the Apex Fm, sole to a major normal listric fault array comprising the entire Salgash Subgroup (not visible at the left-hand side). The fault array merges downwards into the detachment zone consisting of an irregularly and intraformationally folded and sheared basalt with thin chert beds between, in blue, an overlying chert (lefthand side) and a couple of chert beds (just to the left of the car), the upper one of which has been detached from the sheared lower one. Bedding and the $c$. $80 \mathrm{~m}$ thick detachment zone are overturned, $\mathrm{N} 224^{\circ} \mathrm{E} 71^{\circ}$. (a) View to the east; (b, c) details of respectively ductile (in altered basalt) and brittle (in alternation of basalt and competent chert layers) in tight $\mathrm{D}_{1}$ folds within the detachment zone; (d) view to the NW. 
shear zone is evident from field observations on an overprinting relationship of east-vergent folding (with axial plane foliation $\mathrm{S}_{2}$ ) of the first extensional foliation $\left(\mathrm{S}_{1}\right)$, in particular well visible in the serpentinized peridotite sill in this part of the Coppin Gap Sector (Figs 2 and 3) and corresponding stereoplots.

\section{Gorge Range}

We distinguished two fold generations in site 10a: the first is composed of symmetrical $100 \mathrm{~m}$-scale subvertical folds in both flanks of a major $17^{\circ}$ east-plunging syncline (Nijman et al. 1998/ $99 b$, figs 8 and 9). The two fold generations are at right angles to each other. We interpreted the subvertical minor folds to have been formed first, during $\mathrm{D}_{2}$ compression. They have been truncated by a pre- $\mathrm{D}_{3}$ unconformity and subsequently refolded during $\mathrm{D}_{3}$. The same succession of folds has now also been observed at site 10b in the northern tip of the Marble Bar Sector in the southern, opposite limb of the greenstone belt syncline between the Muccan and Mt Edgar Domes.

Site 10c is positioned in the intensely sheared part of the Doolena Gap Belt adjacent to the Muccan Dome. In places almost isoclinal, east-vergent folds with vertical axes parallel to the dip of the bedding appear to have been folded by east-west orientated folds related to the tightening of the greenstone belt. However, we are not sure whether they belong to the $\mathrm{D}_{2}$ or to a later phase of deformation along the contact with the Muccan Dome (cf. Wiemer et al. 2016 for a detailed analysis further westwards in the same fold belt).

Because of the variable plunges of $\mathrm{D}_{3}$ fold axes we refrained from making rotated stereoplots of site 10 .

\section{Marble Bar Sector}

As in the Coppin Gap Sector, the traverse through the Marble Bar Sector spans almost the complete range of stratigraphic units of the Warrawoona Group (Fig. 2). Published data on the Marble Bar Sector are reconsidered (sites 14, 16, 17) and new data are presented ( sites 12,13,15) in particular on the cherts of the McPhee Fm of the Talga Talga Subgroup, here correlated with the cherts of the Dresser Fm in the NP Dome and the Razorback Chert in the Coppin Gap Sector.

\section{Fault patterns in the Coongan and Salgash subgroups}

The Marble Bar Chert, exposed west of the village of the same name (site 16), is composed of black-and-white/red chert, in places intraformationally brecciated to edgewise conglomerate and breccia, and cut by a multitude of chert veins and by several mafic dykes. The Marble Bar Chert and the underlying Chinaman Pool Chert belong to the lower part (former Towers Fm) of the Apex Fm overlying Duffer intermediate volcanic rocks. Oliver \& Cawood (2001) reported both cherts to young southwestwards in steep, overturned position due to doming of the Mt Edgar granitoid complex, and to be dissected in that orientation by a series of northstriking right-lateral faults with associated breccia lenses. Here we postulate that these faults and breccia lenses are due to the same $D_{1}$ synsedimentary extension as observed elsewhere (see also the next section) and have been overturned subsequently. Growth fault control of the Marble Bar Chert has also been reported by Coltice et al. (2012), who characterize the Marble Bar Chert as a deep subaqueous fan (cf. section 'Salgash Basin margin'). When measured fault attitudes in Oliver \& Cawood (2001) are backrotated with the overturned bedding (stereoplot 16) the original north-facing of the faults is evident.

In the Marble Bar Sector, the Duffer Fm is \pm 4000 m thick, but much faulted (Fig. 2). Some faults are bedding-parallel and traceable over tens of kilometres, others are NE-trending at acute angles to the bedding. The Marble Bar 1:100 000 sheet shows an array of such cross-cutting faults dextrally offsetting the top of the Duffer Fm. In the northern part of the Marble Bar Sector this pattern changes into its mirror image (NNW-trending sinistral faults), linking up with the normal fault arrays of the Coppin Gap Sector (cf. section titled 'Coppin Gap Sector' above and Fig. 2).

We consider the bedding-parallel faults in the Marble Bar Sector as shear zones of the same scale and type as those in the Coppin Gap Sector. Van Haaften \& White (1998) distinguished the Duffada SZ (site 16a) along the base of the Duffer Fm, and the McPhee Reward SZ in and along the top of the Talga Talga Subgroup. Another similar shear zone, the Chinaman Pool SZ, is found along the top the Duffer Fm.

The shear zones and the cross-cutting fault arrays have been highlighted in Figure 2; they strongly resemble the $\mathrm{D}_{1}$ growth-fault arrays of the Coppin Gap Sector, though now with roughly northward vergence (stereoplots 14-16), like the ones in the Marble Bar proper (stereoplot 17).

\section{The Salgash mafic dyke swarm in the Marble Bar Sector}

The densily spaced mafic dykes in the southern half of the Marble Bar Sector, first reported by Hickman (1983), have been mapped in detail by Kloppenburg (2003, fig. 4.5) and are also shown in the Marble Bar 1:100 000 sheet. These feeders to the basalts of the Salgash Subgroup belong to the same Salgash dyke swarm as those of the Coppin Gap Sector, but here - after back-rotation to their original orientation using a rotation axis parallel to the local bedding strike - their orientation is at a c. $90^{\circ}$ angle to those in the Coppin Gap Belt.

\section{Deformation in the Talga Talga Subgroup}

The Talga Talga Subgroup in the Marble Bar Sector, composed of North Star Basalt overlain by the chert-bearing McPhee Fm, has been the subject of several studies (e.g. Collins 1989; Van Haaften \& White 1998; Beintema 2003). Folds and faults in the McPhee Fm and the immediately overlying Mt Ada Basalt have been interpreted differently. Collins (1989) measured the irregular fold pattern at the boundary between the McPhee Fm and Mt Ada Basalt. He distinguished two fold generations, the first of which is accompanied by $S_{1}$ foliation, and concluded it represents a NW-facing surficial gravitational folding due to the doming of the Mt Edgar granitoid complex, with the inference that the doming was already active around $3.469 \mathrm{Ma}$ ago. The second fold generation consists of mainly slightly SW-plunging open folds that become more complex towards the hinge of a bulge (named the Talga Talga Anticline by Collins) in the McPhee Rewards strike of the Marble Bar Belt. These folds do not affect a stretching lineation consistently plunging westwards. Van Haaften \& White (1998) analysed the McPhee Reward SZ and Duffada SZ and recognized two early deformations: normal faults facing WNW, followed by piggyback thrusts towards the ESE, an interpretation rejected by Van Kranendonk et al. (2001b) on the basis of undisturbed stratigraphical continuity and lack of structural arguments for thrusting.

We revisited the McPhee Reward area along four erosion gaps providing cross-sections through the formation (Fig. 2, sites $12-$ 15; Fig. 5). Without exception, the transition from the cherts of the McPhee Fm towards the base of the Mt Ada Basalt is characterized by intraformational folding in Mt Ada Basalt, visible at macroscale at site 15 (Fig. 5a and b) and, more frequently, at mesoscale in basalt at site 14 and in intercalated Fe-rich, BIF-type banded cherts at sites 12 and 13 . The folds have the $\mathrm{D}_{1}$ synsedimentary slump geometry often with thickened crests and with a wide spread of fold axis orientations. In their present-day position they are mostly recumbent, conform to the observations of Collins (1989), who also distinguished a second fold generation. We observed an 

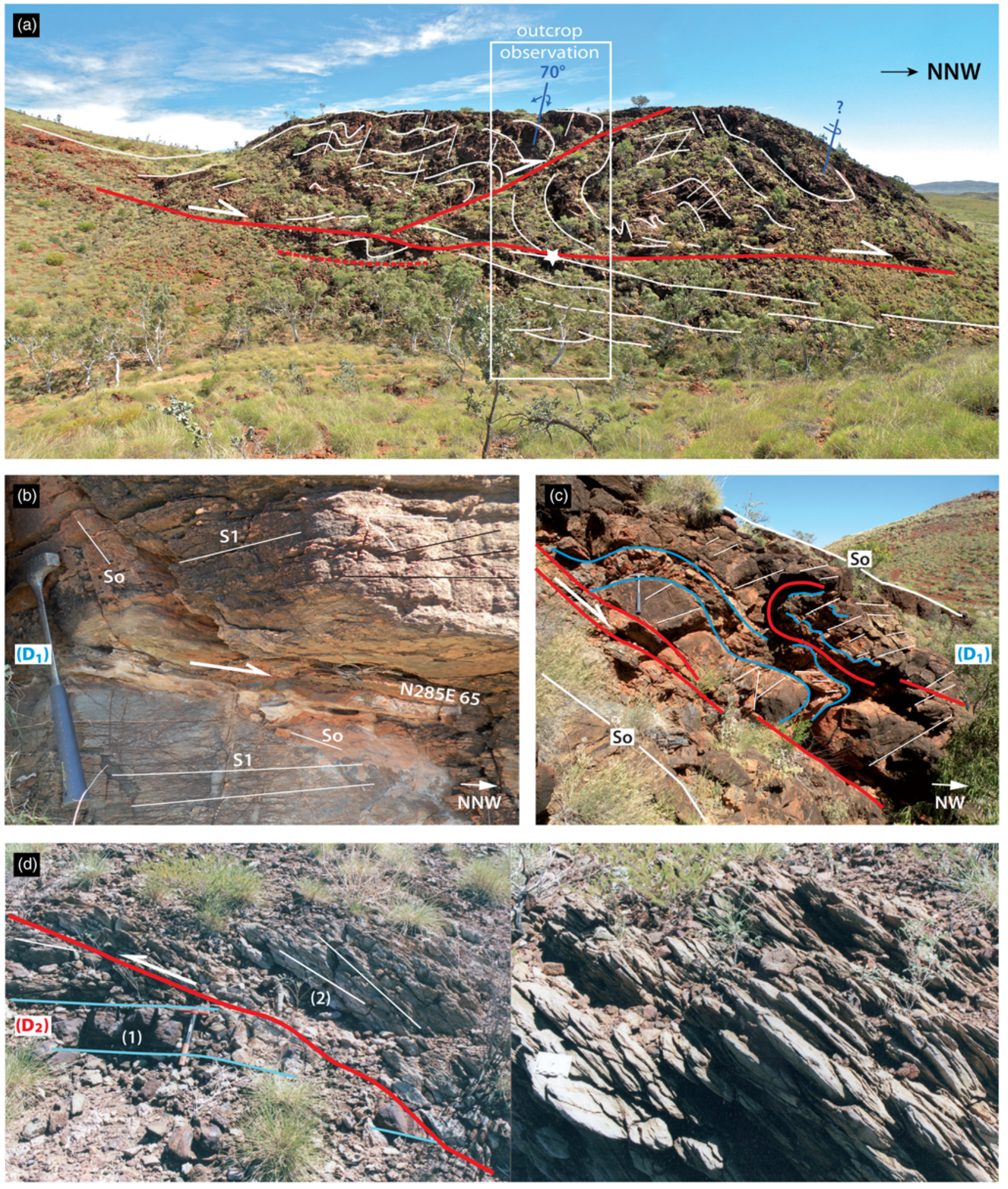

Fig. 5. Marble Bar Sector: McPhee Reward Shear Zone, sites 4, 7 and 8 (location in Fig. 2). (a) $D_{1}$ detachment fault with hanging wall composed of NNWvergent slump-folded Mt Ada Basalt, now dipping $70^{\circ}$ away from the viewer. The footwall consists of regularly bedded basalt and cherts, locally with channel-fill geometry. The complex is sandwiched between the regularly bedded McPhee Fm below and the likewise regularly bedded part of Mt Ada Basalt above (not shown in the figure). Structurally, the deformation is interpreted to be due to gravitational slumping in the toe of basinward-directed growth fault arrays (site 4). (b) Detail of the detachment's shear plane with subparallel foliation (black \& white lines) from outcrop indicated by a star in (a) (site 4). (c) Intraformational $D_{1}$ deformation in downdip displaced Mt Ada Basalt; irregularly folded chert layers (light blue) in between blocky broken-up (pillow-)basalt; red lines: basal shear plane and internal faults; thin lines, developing fracture cleavage; So: little or not disturbed beds of basalt (site 7). (d) $\mathrm{D}_{2}$ fracture cleavage (white lines: $\mathrm{N} 291^{\circ} \mathrm{E} 47^{\circ}$; detail on the right-hand side) in (ultra)mafic rock thrust upon BIF (light blue) belonging to McPhee Chert. Such $\mathrm{D}_{2}$ thrust zones account for duplications in the top of the Talga Talga Subgroup (site 8).

overprint by $\mathrm{D}_{2}$ updip asymmetrical folds, overthrusts and steep foliations (fracture cleavage) (site 12, Fig. 5d; site 13). From stereoplot 13 to 15 the restored $D_{1}$ vergence shifts rapidly from west to north, but the $\mathrm{D}_{2}$ vergence remains constant to $\mathrm{N} 160^{\circ} \mathrm{E}$ in stereoplots $12-14$. Stereoplot 14 is based on the measurements of Collins (1989, fig. 2), back-rotated in the same way as for the other 
stereoplots. It shows the close correspondence with our measurements in the adjacent outcrops to the north (sites 13 and 12). Collins' second generation of folds, if combined with the thrusts and duplication within the McPhee Chert depicted in his figure, has much in common with the $\mathrm{D}_{2}$ structures of this paper, both in style and orientation.

Stereoplot 16, south of site 15 and in the Duffada SZ, is based on the measurements of Van Haaften \& White (1998, fig. 2) and Kloppenburg (2003, fig. 4.5). It confirms the northward $D_{1}$ vergence and gives a $D_{2}$ vergence to the east and $\mathrm{NE}$, which deviates anticlockwise from the SE vergence in that part of the traverse and therefore has to await further evaluation (cf. section 'Gorge Range' above and Fig. 3a).

\section{Glen Herring Synclinorium}

A synclinorium connects the Marble Bar Sector with the NP Dome. The structure is relatively shallow with dip angles generally below $25^{\circ}$. For the greater part the traverse passes through the unconformable cover of basalts and sediments of the Fortescue Group $(<2.8 \mathrm{Ga})$. Only along some longitudinal faults are the underlying Meso- and uppermost Palaeoarchaean rocks exposed. In the basement below the synclinorium there is no evidence (Blewett et al. 2000) for the existence of a major block boundary, like the Mulgandinnah Fault Zone, that might unsettle the straightforward connection made in the traverse (Fig. 3a) between the Marble Bar Sector and the NP Dome.

\section{North Pole Dome}

Below, the focus is on the deformation along the southern, eastern and northeastern flanks of the dome, with special attention to predoming geometries and kinematics.

\section{Construction of the traverse}

The traverse crosses the centre of the NP Dome where an adamellite body has intruded its greenstone cover $c$. 3459 Ma ago. The crosssection preserves true stratigraphic thickness for the east and west flanks of the dome, which has lost its roof by later Meso- and Neoarchaean erosion. Notice the De Grey and Fortescue unconformities cutting deeply into the centre of the dome (Figs 2 and 3a). To compensate for this loss of stratigraphic and structural data, the fully preserved northern and southern flanks have been projected upon the plane of section (Fig. 3a).

\section{Deformation in the south flank of the NP Dome}

The southward track from the Normay Mine at the granitic core of the NP Dome crosses the Dresser Fm (site 19a) and an interval of basalt several hundreds of metres thick with interlayered thin cherts at the level of the Antarctic Creek Mbr (site 19b). Particularly in the cherty intervals of both sequences, decametre-scale west-over-east thrusts and thrust folds with downdip, c. $60^{\circ}$ southward-plunging, fold axes occur frequently and the structural pattern is that of ubiquitous west-over-east bulk shear (stereoplot 19).

In the Panorama Ridge, $3 \mathrm{~km}$ further south along the track and stratigraphically high in the Salgash Subgroup, the Apex Basalt is overlain by a complex of two superposed and relatively thick, southdipping sequences of felsic volcanic rocks and volcaniclastic sandstone of the Panorama Formation, separated by a poorly exposed and sheared body of basalt (Fig. 6 and Supplementary material fig. f). In the context of this paper the observation in this outcrop, both in the field and in oblique downdip air photographs, of piggyback thrusting at several scales is of prime importance. The structures and rotated stereoplot data (stereoplot 18) evidently indicate an east-vergent imbricate thrust system now dipping $60-$ $70^{\circ} \mathrm{S}$ with the bedding. Solid stratigraphical proof of tectonic duplication, however, would require a resolution of the dating beyond that of the current dating techniques. ${ }^{6}$ The observed deformation and stratigraphic duplication also offer an alternative solution to the proposed direct superposition of the Panorama Fm on Duffer Fm volcanic rocks (cf. section 'Remarks on the stratigraphical correlation' above).

\section{Deformation in the NE flank of the NP Dome}

We present two sets of observations in the NE flank of the NP Dome (Fig. 7), respectively at the transitions of the Mt Ada Basalt to the Antarctic Creek member (site 21a-b) and of the Panorama Fm to the Strelley Pool Chert (site 21c);

Mt Ada Basalt-Antarctic Creek Member: The upper part (data for the lower part are unavailable) of the Mt Ada Basalt (site 21a) shows bulk NW-over-SE shear (Fig. 7a), inferred from meso- to macroscale asymmetrical folds with axes parallel to the $\mathrm{N} 25^{\circ} \mathrm{E} 80^{\circ}$ dip direction of the bedding and with subvertical $\mathrm{N} 70^{\circ} \mathrm{E}$ axial planar foliation. The overlying chert unit of the Antarctic Creek Mbr, on the other hand, is intraformationally folded in an irregular box-fold pattern, characteristic of slump folding, but with an overall westfacing asymmetry (site 21b; Fig. 7b). A similar fold pattern is found in the basal chert of the Apex Fm in the Bamboo Creek Sector (cf. section 'Bamboo Creek Sector' above), in the BIF along the base of the Duffer Fm in the Coppin Gap Sector (cf. section 'Coppin Gap Sector' above), and in the top cherts of the McPhee Fm (cf. section 'Deformation in the Talga Talga Subgroup' above). Since in several of these chert outcrops this type of folding is overprinted by $\mathrm{D}_{2}$ compressional structures, the deformation of the Antarctic Creek Mbr in the NE flank of the NP Dome is also assigned to $\mathrm{D}_{1}$ and the NW-over-SE shear in the underlying Mt Ada Basalt to $\mathrm{D}_{2}$ (stereoplot 21).

Panorama Fm: The satellite image interpretation of Figure $7 \mathrm{c}$ illustrates the same sequence of events in the $\mathrm{N} 35^{\circ} \mathrm{E} 65^{\circ}$-dipping Panorama Fm exposed in the ridge $3.5 \mathrm{~km}$ further to the NE (site 21c; Supplementary material fig. g). $\mathrm{D}_{2}$ west-over-east thrusting prevails, where marked in the figure accompanied by thrust folds and local back thrusts. Apart from this pattern of shortening, an overall trend of northwestward stratigraphical increase of thickness, in places with abrupt NW-block down offsets, and a rollover anticline with local unconformity (utmost left in Fig. 7c) bear witness to the preceding $\mathrm{D}_{1}$ extension.

\section{Deformation in the east flank of the NP Dome}

For the North Pole Chert of the Dresser Fm, a NNW-vergent $D_{1}$ growth-fault mechanism controls the sedimentary architecture and the distribution of the hydrothermal baryte-chert vein (Nijman et al. 1998/99a; stereoplot 20). Also some overturned east-vergent thrusts have been observed near the Dresser Mine and such $\mathrm{D}_{2}$ minor thrusts are abundant further south in the same cherts at site $19 \mathrm{a}$ (cf. section 'Deformation in the south flank of the NP Dome').

Outside the Dresser Fm, structural data from the east flank of the NP Dome are fragmentary. A shear zone runs parallel to the Antarctic Creek Mbr. The exposure is poor and a single fold was found with a mere $22^{\circ}$ axial plunge to $\mathrm{N} 60^{\circ} \mathrm{E}$ in a $100 \mathrm{~m}$ wide zone of disturbed, highly calcified and altered basalt (site 22). The shear zone coincides with the most easterly of two major north-striking faults in the North Shaw 1:100 000 map sheet. The two faults appear to have functioned as soles to north-trending arrays of left-stepping cross-cutting faults (Fig. 2), the mirror-image of such fault arrays in the Marble Bar Sector. The map suggests that the easternmost,

${ }^{6}$ cf. footnote 4; Kitajima et al. (2008) place a major thrust plane along the top of the Strelley Chert, which we were not able to detect. 


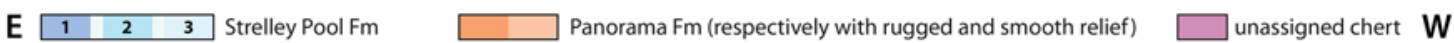
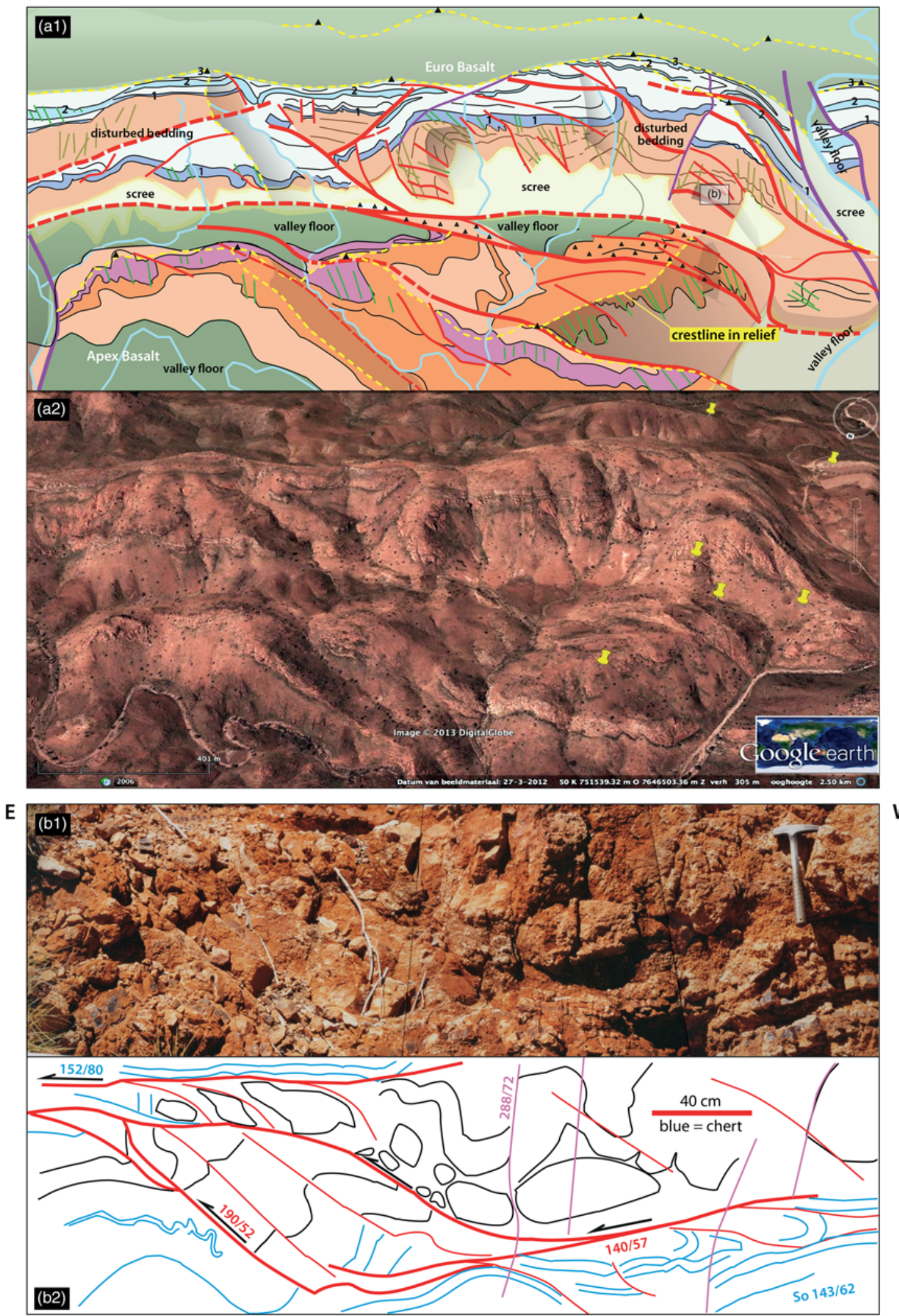

Fig. 6. Panorama Ridge, south flank North Pole Dome, site 18 (location in Fig. 2). (a1, 2) Interpretation (1) of oblique, stratigraphically downdip (c. $\left.65^{\circ} \mathrm{S}\right)$, aerial photo view (2) of two tectonically superposed units each composed of chert-capped Panorama Fm, with a severely sheared basalt in between. The lower sequence consists of coarse-grained porphyritic volcanic/volcaniclastic rock topped by chert. Further to the west this part of the Panorama Fm has been dated at $3458 \pm 2 \mathrm{Ma}$ (Thorpe et al. 1992), isochronous with the emplacement of the adamellite core of the NP Dome). The upper unit is of comparable composition, interlayered with decametre-thin chert beds (see detail in (b)). The capping sedimentary chert is about ten metres thick, overlain by two more sedimentary chert layers alternating with basalt (Strelley Pool Fm) in the transition to the overlying Euro Basalt. The Panorama volcano-sedimentary complex has been thrust-folded due eastwards, with formation of duplex structures at a scale of several hundreds of metres (see also Supplementary material fig. e). In places, folding is disharmonious because of differences in competence between the felsic volcanic rocks and the cherts. Fracture cleavage indicated as green lines. Yellow pins mark the sites of field observations. $(\mathbf{b 1}, 2)$ Detail at mesoscale reproducing the deformation at megascale (location in rectangle in (a)) 


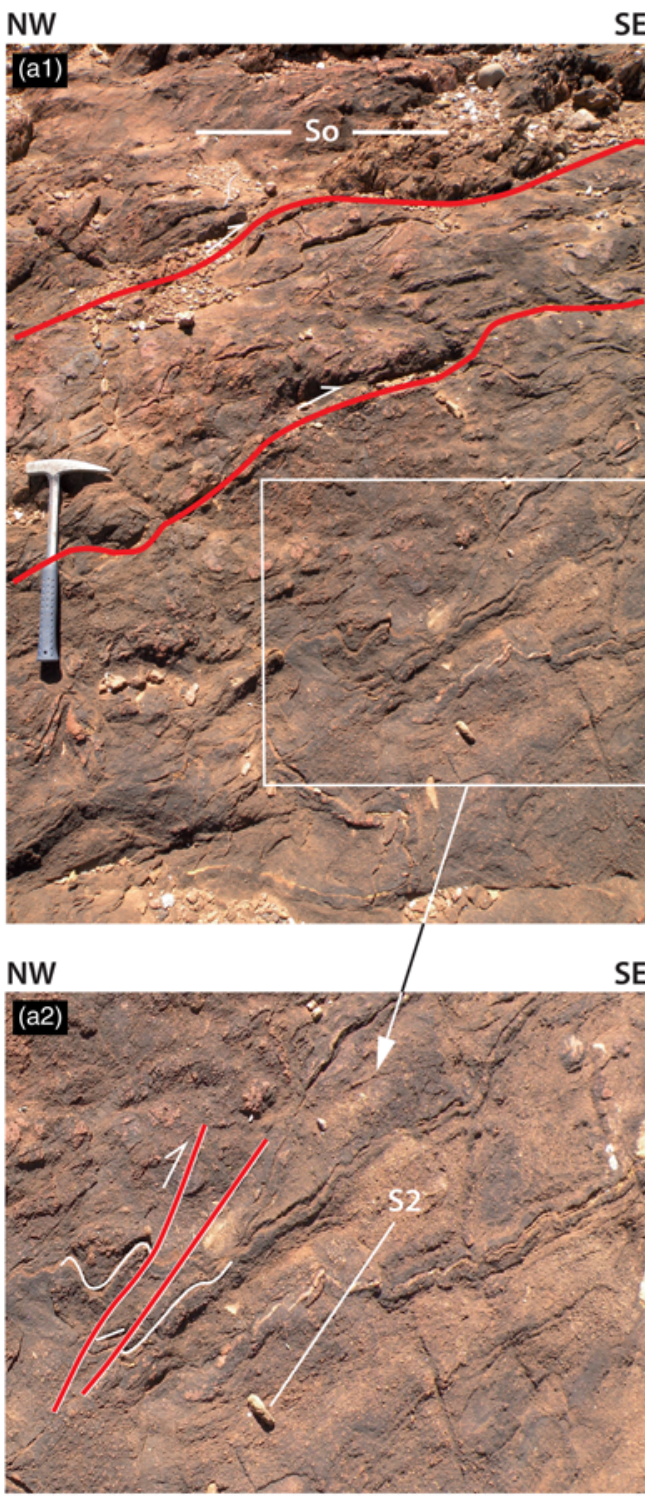

$\left(D_{2}\right)$

SE
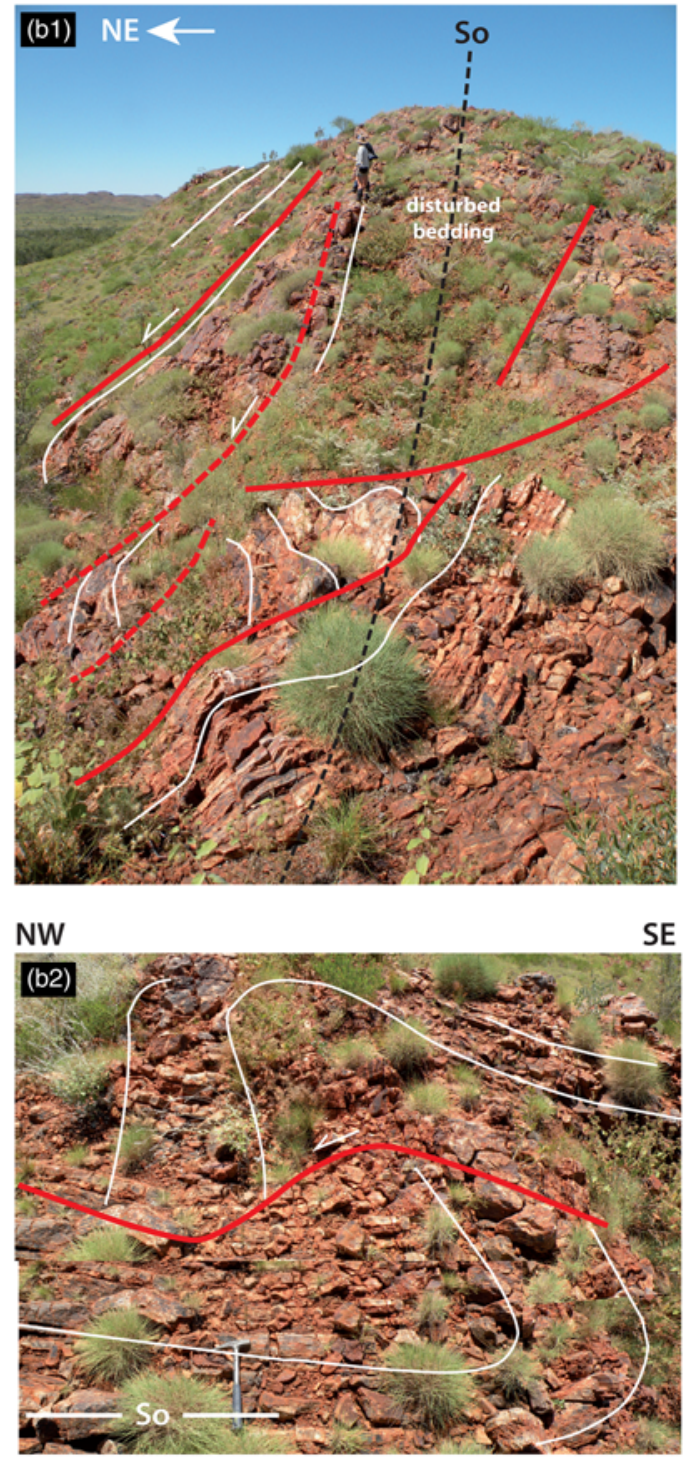

$\left(D_{1}\right)$

(c) Panorama volcano-sedimentary complex, NE North Pole Dome

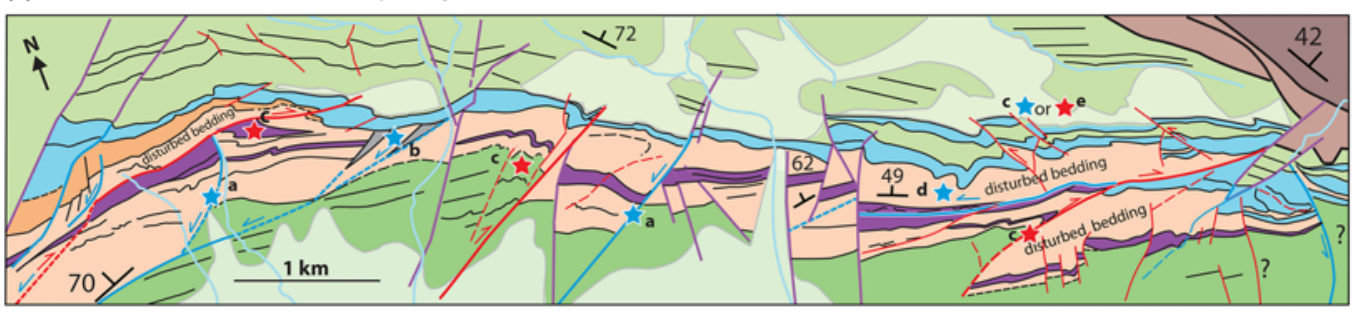

Panorama volcano-sedimentary complex

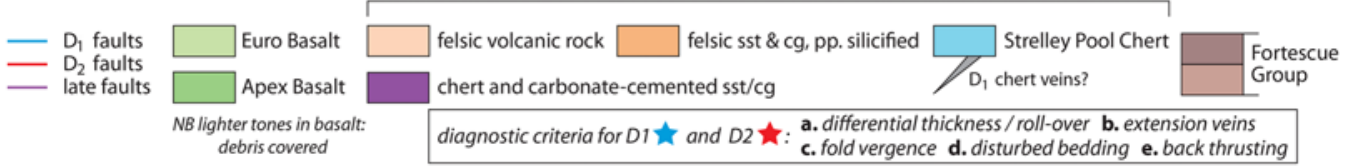

Fig. 7. NE flank North Pole Dome, site 21a-c (location in Fig. 2). (a1, 2) Over hundreds of metres the upper Mt Ada Basalt shows bulk NW-over-SE shear of the type illustrated here (site 21a). This $\mathrm{D}_{2}$ pattern of deformation is mirrored at the same stratigraphic level along the south flank of the dome (site 19). $(\mathbf{b 1}, 2) \mathrm{NW}$-vergent asymmetrical folds and minor thrusts, accompanied by local chaotic disruption of the bedding in the chert layer at the very base of the Apex Fm (site 21b, Antarctic Creek Member), overlying the outcrop of Mt Ada Basalt of (a). This intraformational folding is characteristic of the $\mathrm{D}_{1}$ phase of synsedimentary slope-driven deformation. (c) Oblique aerial photo interpretation (for the Google Earth base of the interpretation see Supplementary material fig. g) of the Palaeoarchaean sequence of uppermost Apex Basalt, the Panorama-Strelley Pool Chert volcano-sedimentary complex, and Euro Basalt, unconformably covered by the Neoarchaean Fortescue Group, in the NE flank of the North Pole Dome (site 21c; lithostratigraphy partly based on 1:100 000 North Shaw and Marble Bar sheets). Deformation is dominated by SE-vergent $\mathrm{D}_{2}$ thrusting (red stars), predating the forming of the North Pole Dome (see text and compare Fig. 6). Structures interpreted to predate the thrusts $\left(\mathrm{D}_{1}\right.$ or $\mathrm{D}_{1}$-related; blue stars) are: abrupt NW-down stratigraphic thickenings along inherited (growth-)faults (in blue), a rollover anticline, zones of disturbed bedding, and an overall westward stratigraphic expansion of the Panorama Fm. 
stratigraphically upper array ends in an irregularly folded body of basalt with cherts, much resembling, slump-folded units related to originally subhorizontal $\mathrm{D}_{1}$ extensional shear zones elsewhere.

\section{The East Pilbara traverse interpreted and restored}

\section{Taking account of pre-doming deformation}

A stepwise restoration of the traverse towards its state during deposition of the $3.47-3.42$ Ga old volcanic and sedimentary rock sequence requires insight into the timing of the observed deformations with respect to the tilting of the rock sequence and development of the presently visible domes.

$D_{1}$ extension: Because the $\mathrm{D}_{1}$ extension produced synsedimentary growth-fault patterns unrelated to the configuration of the $D_{3}$ domes, it is evident that this first phase of deformation precedes doming. The $\mathrm{D}_{1}$ phase will be discussed further in the later section 'The traverse during pre-3.3 Ga extension'. The observed beddingparallel shear zones contain extensional and compressive foliations and other structures, sometimes spatially separated from each other, sometimes as structural reversals at the same locality. Together with the stratigraphic rock sequence, they have been deformed by doming and they do not have any causal relationship with the actually visible dome-and-belt geometry. They must have been generated early in the structural history, before doming and synformal bending of the greenstone belts and cannot be regarded as ring faults to diapiric granite domes (Van Kranendonk 2004), although reactivation during doming cannot be excluded. The role of shear zones is considered to be fundamental in developing structural models of the early Archaean crust (cf. De Wit et al. (2011) for a comparable situation in the Barberton Greenstone Belt of South Africa).

$D_{2}$ compression: Since the first accounts of early pre-doming compression (Bickle et al. 1980; Boulter et al. 1987; cf. for Barberton: De Wit 1982), its existence and timing are subjects of debate. The point is whether the observed folds are generated by doming and sagduction as a result of crustal overturn (Collins et al. 1998; cf. Van Kranendonk et al. 2015a, fig. 8) or otherwise by regional tangential stress without clear evidence of such vertical crustal movements (Zegers 1996; Blewett 2002) and/or by the synsedimentary extension preceding it. In the former case, a two-tier crustal model of greenstone on top of felsic rock must have played a role already early during the development of a Palaeoarchaean protocontinent (Hickman 2012a). In the case of regional compression a plate tectonic drive is often advocated.

$D_{3}$ doming-related compression: $\mathrm{D}_{3}$ structures playing a role in this article are folds related to the tightening of the greenstone belt synclines, and the doming of the granitoid complexes during crustal turnover. They are only important for the subject of this paper in so far as they refold earlier structures, which can then be recognized as $\mathrm{D}_{2}$ or $\mathrm{D}_{1}$

\section{The traverse during 3.3 - 3.2 Ga compression $\left(\mathrm{D}_{2}\right)$}

Our data reveal a much wider spread of $\mathrm{D}_{2}$ compressive structures than previously recorded. Successively, the timing, the geometry and the stress field orientation will be discussed.

\section{Restoration of the traverse to $\mathrm{D}_{2}$ times}

To be able to study the geometry of the traverse at $\mathrm{D}_{2}$ times, post- $\mathrm{D}_{2}$ deformations have been restored from the cross-section of Figure $3 \mathrm{a}$. In our model this is the majority of the folding and steepening of the greenstone belt sequences (e.g. folding of the Glen Herring Synclinorium and the Bamboo Creek Syncline), and late faulting (e.g. in the Coppin Gap Sector: the Talga Talga River and Box Soak faults; the radial faults in the NP Dome). Figure 3 illustrates that the post- $\mathrm{D}_{2}$ deformation resulted in a shortening from 119 to $103 \mathrm{~km}$, i. e. of $13.5 \%$ over the length of the traverse.

In the $\mathrm{D}_{2}$ traverse (Fig. $3 b$ ) all relevant $\mathrm{U}-\mathrm{Pb} \mathrm{Zr}$ datings from the corridor map of Figure 2 have been inserted in their proper stratigraphic positions. Hereafter, they will be used for the reconstruction of the isochrones in the next step of restoration, the $\mathrm{D}_{1}$ traverse of Figure $3 \mathrm{c}$.

\section{Pre- to syndoming character of $D_{2}$ compression}

As to the relative timing of $\mathrm{D}_{2}$ and $\mathrm{D}_{1}$, our observations in the NP Dome are of prime importance. At the time of $\mathrm{D}_{2}$ compression the North Pole adamellite intrusion $(3459 \pm 18 \mathrm{Ma}$ ) had already been emplaced - probably as a laccolith - in the lower part of the Warrawoona Group, but it did not primarily account for the actual shape of the NP Dome (Van Kranendonk 1999, 2000; Blewett et al. 2004). Rather, the domal shape was induced by the formation of the major granitoid domes in the surroundings in the way it was suggested for the McPhee Dome, north of the Mosquito Creek Basin, much further to the SE in East Pilbara (Nijman et al. 2010).

The $\mathrm{D}_{2}$ folds observed in the NE flank mirror those in the south flank (compare Figs 6 and 7). In both flanks of the dome the fold axes are parallel to the dip direction of the bedding and the folds have the same roughly eastward vergence. We conclude that $D_{2}$ structures are tilted with doming and that $D_{2}$ compression started before the main phase of doming of the NP Dome.

Zegers (1996) places the east-west compression between either 3325 or 3309 and $3200 \mathrm{Ma}$. With respect to the timing of the start of $\mathrm{D}_{2}$ compression our observations allow (cf. section 'Coppin Gap Sector' above) for three scenarios.

(1) If the Coppin Gap Granodiorite intrusion dissects $D_{2}$ structures of the Razorback SZ (De Vries et al. 2006), the age of the intrusion (c. $3314 \mathrm{Ma}$ ) provides a minimum age for the start of $\mathrm{D}_{2}$.

(2) If $\mathrm{D}_{2}$ shear interfered with/was obstructed by synkinematic intrusion of the granodiorite, the age of the intrusion determines the maximum age of $\mathrm{D}_{2}$.

(3) If $\mathrm{D}_{2}$ shear has stepped to higher stratigraphic levels by ramping along the western boundary of the already existing intrusive body, the start of compression may even have been considerably later than $3314 \mathrm{Ma}$.

East of the granodiorite body, structures related to $D_{2}$ thrusting are not observed below the structural/crustal level of the Bamboo Creek SZ, suggesting a sort of shadow effect for eastward propagation of $\mathrm{D}_{2}$ deformation behind the intrusion, an argument in favour of the latter two scenarios. In the Mount Edgar Dome two relative young granites have been mapped belonging to the $c .3315 \mathrm{Ma}$ Emu Pool (comprising also the Coppin Gap Granodiorite) and c. $3245 \mathrm{Ma}$ Cleland supersuites (Williams \& Bagas 2007a, b). If synkinematic, these granite intrusions would tally with the two phases of thrusting: an early one (first two scenarios) during Wyman felsic volcanism (not preserved in the traverse area except for a thin tectonically isolated sliver in the Talga Talga Range near site 7 and dated $3318 \pm$ $4 \mathrm{Ma}$, De Vries et al. 2006) and a later one (third scenario) synNimingarra BIF (c. $3.19 \mathrm{Ga}$ ), with an unconformity in between. Taking into account all observations, we will work with the scenario of a double-phased progressive $\mathrm{D}_{2}$ compression from at least $c .3 .31$ to $c .3 .19 \mathrm{Ga}$

\section{Ramp-and-flat thrust geometry and the amount of shortening}

Tectonic duplication: The $\mathrm{D}_{2}$ low-angle thrust geometry and the apparent lack of significant shortening by datable duplication have been discussed previously (Nijman \& De Vries 2004; De Vries et al. 2006). Continuity within the stratigraphic succession does not 
contradict deformation along shear zones when it concerns beddingparallel slip in a flat-and-ramp geometry, with dominance of the flats. And, as yet, the present-day geochronological resolution cannot reveal a duplication of stratigraphic units of more or less the same age that may have formed in less than a million years. Thrusting with such velocities is, for instance, known from Alpine deformation, such as in the Helvetic Nappes of Switzerland ( $2 \mathrm{~km} \mathrm{Ma}^{-1}$, Sinclair et al. 1991) and the South Pyrenean foreland basin (5 $\mathrm{km} \mathrm{Ma}^{-1}$, Nijman 1998).

Where the outcrop is at right angles to the $\mathrm{D}_{2}$ fold axes, as in the south and NE flanks of the NP Dome and in Bamboo Creek Sector, the thrust geometry is well visible. Where, on the other hand, the outcrop is roughly parallel to the $\mathrm{D}_{2}$ axes, the thrust structures would be more difficult to detect. This may be the case in the actually flat erosion surface of the east flank of the NP Dome. Tectonic duplication is suggested there by: (1) doubling of the thickness of the Apex Fm from c. $200 \mathrm{~m}$ in the west flank to $c .450 \mathrm{~m}$ in the east flank (Fig. 3a and $b$ ); and (2) the presence of two, now east-dipping north-facing normal faults arrays (Fig. 2), interpreted by us as $\mathrm{D}_{1}$ structures, at the level of the Antarctic Creek Member (cf. section 'Deformation in the east flank of the NP Dome). Elsewhere in the NP Dome this unit forms only one single interruption in the thick sequence of Mt Ada and Apex basalts. The intense $\mathrm{D}_{2}$ west-over-east bulk shear observed in the southern and northeastern flanks of the NP Dome indicates the concentration of $\mathrm{D}_{2}$ strain at and around this stratigraphic level.

Imbricate thrusts occur also in the top of the Talga Talga Subgroup at the McPhee Reward (site 12) and in the hanging wall of the Bamboo Creek SZ in the Bamboo Creek Sector (sites 3 and 5). The youngest formation involved is the unconformable BIF of the Nimingarra BIF.

$\mathrm{D}_{2}$ shortening: Due to a lack of pin points for a fully constrained balancing of the cross-section, the calculated amount of $\mathrm{D}_{2}$ shortening is a minimum estimate. Many uncertainties remain, particularly in the Glen Herring Synclinorium and around the Mulgandinnah Fault Zone in the west. Westwards of that major fault zone, a huge hiatus separates the Coonterunah Subgroup (3515 \pm $3 \mathrm{Ma}$ ) from the Strelley Pool Chert (c. $3440 \mathrm{Ma}$, interpreted to cap the Panorama Fm in the East Pilbara). At $3238 \pm 2$ Ma the Strelley Granite intruded into Euro Basalt coeval with the deposition of the Sulphur Springs and Soanesvilles Groups (3280 - 3190 Ma). East of the Mulgandinnah Fault Zone, time-equivalent rocks are only present in the Gorge Range (Coongan 1:100 000 sheet) and, as Nimingarra BIF, in the Coppin Gap Sector (Muccan 1:100 000 sheet).

Taking all uncertainties into account, the restoration of Figure $3 \mathrm{~b}$ results in a shortening of some $20 \mathrm{~km}(14.5 \%)$ with respect to the $139 \mathrm{~km}$ length of the pre- $\mathrm{D}_{2}$ traverse of Figure $3 \mathrm{c}$. Exclusive of the unknown amount of $D_{1}$ extension, the cumulative $\left(D_{2}+D_{3}\right)$ estimated shortening over the traverse then amounts to $28 \%$.

\section{$N W-S E D_{2}$ stress field orientation}

Once the prevailingly pre-doming character of $\mathrm{D}_{2}$ is recognized, simple backward rotation of structures of that phase over the entire area of the corridor map and adjacent areas to the south (red arrows in stereoplots in Fig. 2) shows a pattern of thrusting in an overall NW-SE-orientated stress field (Fig. 8) (cf. the east-west stress field in Zegers 1996). However, the $D_{2}$ trajectories and transport directions derived from kinematic indicators do not line up completely. We interpret the convergence over the NP Dome and the divergence around the Mt Edgar Dome and the location of thrust ramps and imbricates in Figure 4 as the result of lateral (convergence of trajectories) or vertical constriction (upslope transfer) due to interference of the thrusting with what might be interpreted as initial doming.

Kloppenburg (et al. 2001; 2003, fig. 2.10, pp. 66ff.) report extension in the Mount Edgar Dome and the southern Marble Bar Belt (previously Warrawoona Belt) to have taken place at about
$3315 \mathrm{Ma}$, i.e. concurrent with the early phase of $\mathrm{D}_{2}$ compression in the first scenario mentioned above (cf. section 'Pre- to syndoming character of $\mathrm{D}_{2}$ ' above). NW-SE compression will enhance NE-SW extension along the $\mathrm{b}$-axis of the compression field (i.e. the green lines in Fig. 8). After a short interval of NE-SW compression, not found or represented as an unconformity in the traverse area, a phase of NW-SE transpressive dextral strike-slip then matches with the corresponding second phase (c. $3.24 \mathrm{Ga})$ of $\mathrm{D}_{2}$ thrusting. According to Zegers (1996) and Kloppenburg et al. (2001), the strike-slip was concentrated along the Central Warrawoona Shear Zone, which served as an east-west dextral transfer fault between two domains of opposite vergence at that time (Fig. 8).

\section{The traverse during pre-3.3 Ga extension $\left(D_{1}\right)$}

\section{Stacking of $D_{1}$ normal growth-fault arrays in an arcuate stress field}

The $\mathrm{D}_{1}$ intraformational arrays of listric normal faults occur over the entire stratigraphic column of the Warrawoona Group (Fig. 2); a much wider spread than previously thought.

Restoration of the post-extension tilt of the shear zones and kinematic indicators has shown a systematic pattern of these $\mathrm{D}_{1-}$ vergences (blue arrows in Fig. 2), confirming and extending earlier observations by Nijman \& De Vries (2004). The vergences turn from due west (in the Coppin Gap Sector) via NW (in the McPhee Reward of the Marble Bar Sector and the north flank of the NP Dome) to due north (in the southern part of the Marble Bar Sector and NP Dome). The range of orientations covers a quarter-circle. So, for $D_{l}$, we are evidently dealing with a radial stress field at a scale that is larger than the present-day granitoid domes, at least at upper crustal levels, in contrast with the unidirectional compressional field of $\mathrm{D}_{2}$.

The normal fault arrays are superposed upon each other at different orders of magnitudes. Stacking of growth fault arrays seems to be the rule, whereby the vergence of the fault arrays per location remains the same over c. $40 \mathrm{Ma}$, independent of their stratigraphic position (see also De Vries et al. 2006). Towards their toes some fault arrays are observed to pass into thrusts, slumps, or breccia (e.g. basal Duffer Fm between sites 8 and 14; the frontal thrusts in the Kittys Gap volcanosedimentary complex; and probably also the faulted fold pattern of the Antarctic Creek Mbr in the NW sector of the NP Dome).

This type of architecture is known from basin margin settings, such as the west African and the Gulf of Mexico continental shelfs, where gravity slidings on particular efficient bedding-parallel detachments cause extensional faults upslope largely balanced by contractional thrusting at the downslope toe of the system (Mandl \& Crans 1981; Mauduit \& Brun 1998). The stress distribution in such systems is a function of the basin geometry with $\sigma_{\mathbf{3}}$ downslope, changing to slope-parallel at the toe, and with $\sigma_{1}$ either vertical (high sediment load), or slope parallel.

Combining the arcuate and the proximal-to-distal distributions of the $\mathrm{D}_{1}$ structures, a zonation of growth fault domains (Fig. 2: A-C in light blue) becomes discernible: predominance of (1) vertically stacked listric normal growth fold arrays, with proximal heads; (2) likewise stacked arrays with well-developed dyke swarms; and (3) chaotic, brecciated and/or slump-folded distal growth-fault toes. Like the growth fault arrays, these toe structures are of different scale and nature, and must not be confused with $\mathrm{D}_{2}$ contractional structures.

\section{Palaeoarchaean volcano-sedimentary collapse basins}

\section{Superposed basins}

When the downslope directions of gravitational growth faults are combined with sedimentological information from facies changes 


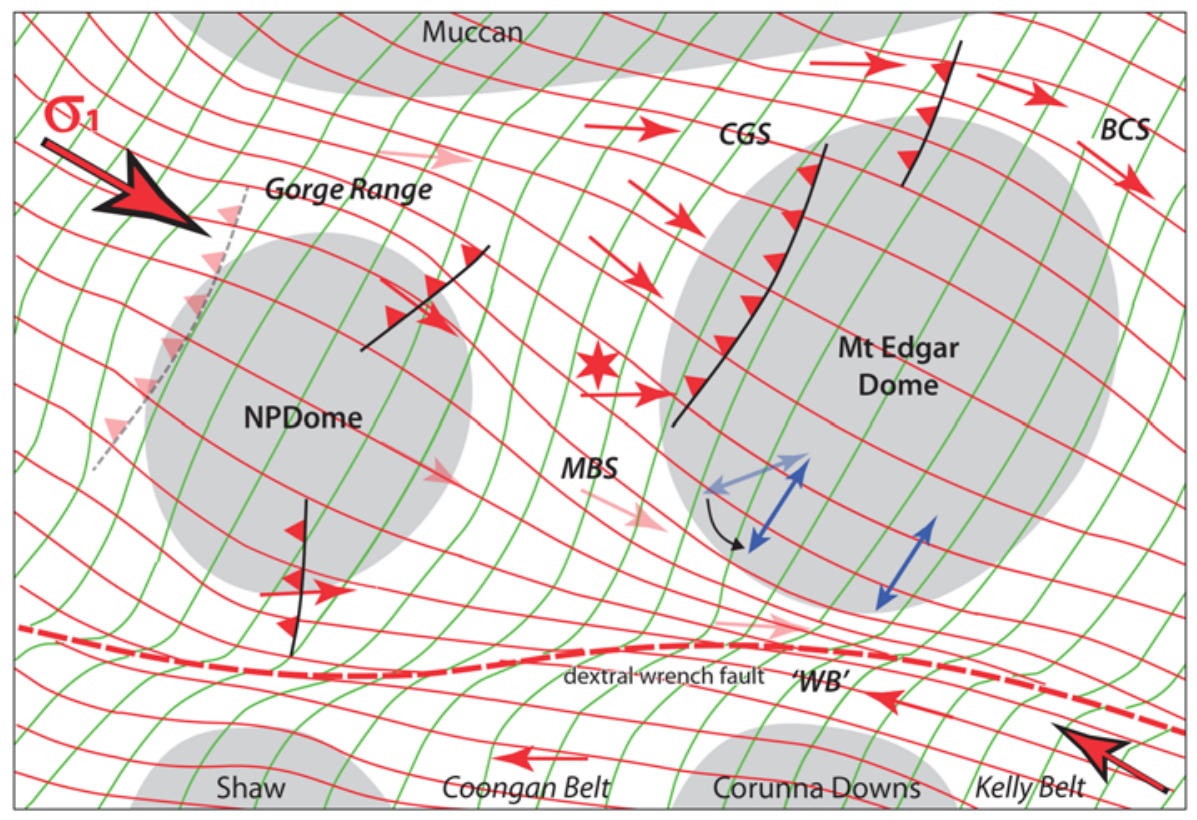

Fig. 8. Stress trajectory model of the $\mathrm{D}_{2}$ NW-SE compressive stress field with SE vergence, interfering with $\mathrm{D}_{3}$ initial domeand-belt formation. Full red arrows show the fanning of $D_{2}$ vergence derived from stereoplots in Figure 2. Inferred structures and vergences vaguely red-coloured. The westward vergence in the lower part of the figure is taken from observations in the Coongan Belt by Zegers (1996) and in the Warrawoona Belt ('WB') by Kloppenburg (2003). The star indicates the deviating vergence of site 16 , probably influenced by more complex deformation than applied here for back-rotation. The blue arrow in the SW corner of Mt Edgar granitoid complex indicates 3424 Ma pre$\mathrm{D}_{2}$ extension lineations (Kloppenburg 2003), which may have been rotated from an unknown D -position into the one at right angles to the $\mathrm{D}_{2}$ compression. $\mathrm{BCS}$, Bamboo Creek Sector; CGS, Coppin Gap Sector; MBS, Marble Bar Sector; NP, North Pole. and/or current markers, they provide a reliable means to detect the basin margin and to unravel the basin architecture.

In the pre- $\mathrm{D}_{2}$ restoration of the traverse (Fig. 3c), an architecture of superposed basin fills (I-IV in Fig. 3c), more precisely basin margins, becomes visible. From the control points in Figure 3b, 10 Ma-isochrons have been constructed. Two basin margin sequences (separated by the white line in Fig. 3c) are recognized: the Coongan Basin margin (II) and the Salgash Basin margin (III) (nomenclature according to the stratigraphic subgroups involved, cf. Fig. 1). The underlying older, rather homogeneous Talga Talga Subgroup of mainly (ultra)mafic volcanic rocks, sealed by the Dresser/McPhee/ Razorback Chert may represent an earlier $(>3.47 \mathrm{Ga})$ basin fill (I), incompletely exposed at its base. Likewise, the Euro Basalt might represent the onset of another, now top-missing, basin fill (IV).

\section{The Coongan Basin margin}

The Coongan Basin fill is composed of Mt Ada Basalt and Duffer Fm and covers a time span of merely $9 \mathrm{Ma}(3470-3461 \mathrm{Ma})$. It displays a distinct lateral change of thickness and facies. From east to west the thickness decreases from c. $5000 \mathrm{~m}$ in the Coppin Gap Sector to $c .1500 \mathrm{~m}$ in the western NP Dome (Fig. 3c). The maximum thickness is entirely due to the accumulation of intermediate to felsic volcanic rocks in the hanging walls of the major growth faults defining the perimeter of the basin; this relationship suggests the faults to have functioned as feeders for the extrusion. The minimum thickness of the Coongan Basin fill is obtained along the western side of the NP Dome, where also the Duffer Fm itself pinches out into the Antarctic Creek Member. In between these extremes, in the Marble Bar Sector, the considerable thickness of the Duffer Fm may be apparent since it has been affected by displacements during $\mathrm{D}_{1}$ and $\mathrm{D}_{2}$ along the aforementioned shear zones.

In general, the frequently pillowed basalts of the Warrawoona Group are interpreted to be submarine, probably of shallow oceanic plateau origin (cf. Arndt 1999; Van Kranendonk et al. 2015a). On the basis of sedimentological criteria, the felsic volcano-sedimentary complexes have been interpreted (De Vries et al. 2010) as regressive-transgressive sequences. In the Kittys Gap volcanosedimentary complex, for instance, the regressive maximum was reached at about sea-level in the capping chert; in the Buck Ridge volcano-sedimentary complex of the South African Barberton Greenstone Belt, the maximum is located in the lower part of the felsic volcanic sequence. In the Coongan Basin, the sequence from Mt Ada Basalt via the growth-fault-controlled intermediate to felsic volcanic Duffer Fm into overlying basalt, as observed in the Coppin Gap and Bamboo Creek Sectors, represents another example of such a regressive-transgressive sequence. The combination of upslope growth faults and maximum regression marks the proximity of the basin boundary. Maximum thicknesses due to, in particular, intermediate to felsic volcanic emanations were concentrated along the faulted basin boundary (Fig. 9), while the thinner mainly basaltic sequence in the NP Dome is interpreted to have been located more basinward.

\section{The Salgash Basin margin}

Chronostratigraphically, the Salgash Basin encompasses the 26 million years between 3460 and $3434 \mathrm{Ma}$. Enriched in cherts and sandstones, the base of this basin margin deposystem tract can be traced over the entire length of the traverse (the former Towers Fm; now lower Apex Fm: Fig. 3c). Considering the configuration of time lines in Figure 3c, this facies overlies an eastwards timetransgressive interface tentatively interpreted as an onlap surface. Recently, the Marble Bar Chert has been characterized as a submarine fan deposystem (Coltice et al. 2012), which is consistent with the interpretation of the base of the Salgash Basin sequence as a transgressive surface. The same stratigraphic unit (former Towers Fm) contains meteorite impact layers, recognized both in the NP Dome (Byerly et al. 2002; Kitajima et al. 2008; Glikson \& Vickers 2010) and at Marble Bar (Glikson et al. 2016). Given the constant basin position during the entire Warrawoona Group time of deposition and the absence of other diagnostic sedimentary and tectonic structures, no causal relationship appears to exist between the extensional basin in the East Pilbara and a meteorite impact (cf. Nijman \& De Vries 2004). However, it cannot be completely excluded that a major impact elsewhere could have disturbed the crustal balance, to a degree that it may have influenced the superposition of the Salgash Basin upon the Coongan Basin.

The Salgash Basin margin compares with that of the Coongan Basin in the continued growth-fault control. This is best demonstrated in the Coppin Gap Sector south of the Kittys Gap volcanosedimentary complex where the $3.46 \mathrm{Ga}$ isochron makes a downward jump of over $2 \mathrm{~km}$ to the west. The accommodation space created is filled here with a combination of Apex Basalt with 


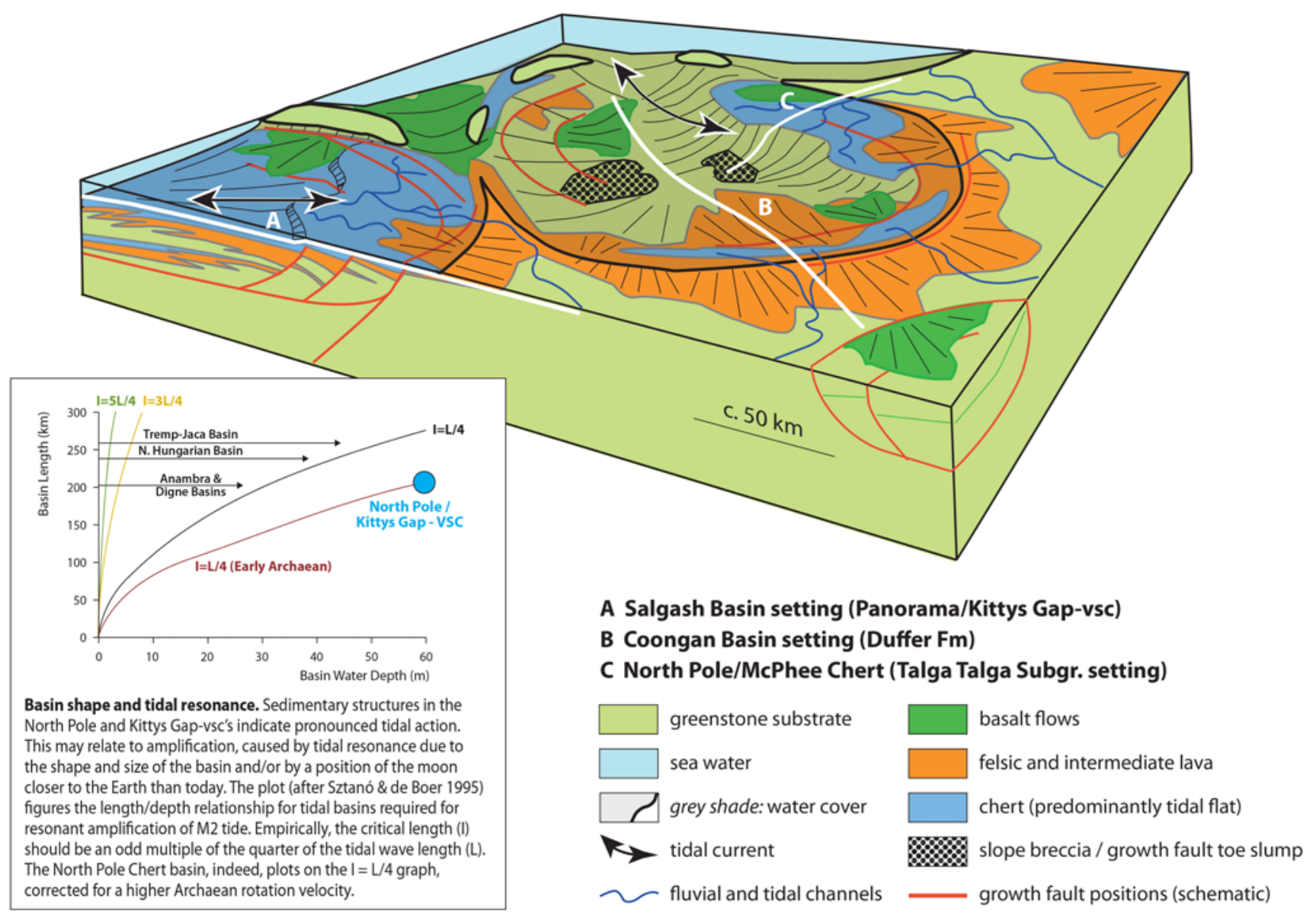

Fig. 9. Proposed basin settings for the Panorama-Strelley Pool/Kittys Gap volcano-sedimentary complex (vsc; Salgash Basin), the Duffer Fm (Coongan Basin) and the Dresser Fm (Talga Talga Subgroup). The basins are interpreted to have been generated by crustal collapse (see Fig. 10) and situated at or near the coastline. Tidal action may have been amplified by the basin shape (see inset figure after Sztanó \& De Boer 1995).

intercalated chert and sandstone components (former Towers Fm), $3458 \mathrm{Ma}$ old lower Panorama felsic units and the largely serpentinized Gap dunite/peridotite sill (Williams 1998; Fig. 3c; Supplementary material fig. e).

Composition and spread of the felsic rocks in the Salgash Basin, however, differ from those in the Coongan Basin. Often rhyolitic, they are definitely more acidic than the Duffer rocks (already mentioned by Hickman 1983), in places their volcanic vents have been preserved (Van Kranendonk et al. 2001a), and they are rich in hydrothermal black chert vein systems feeding into the capping chert (Nijman et al. 1998/99a; Orberger et al. 2006; Westall et al. 2006; Van den Boorn et al. 2007). As discussed above (sections 'Remarks on the stratigraphical correlation' and 'Deformation in the south flank of the NP Dome'), a depocentre of Panorama felsic rock was situated along the south side of the NP Dome (3454 $\pm 2,3458 \pm$ $6 \mathrm{Ma})$, with relatively thin sheets of the same age $(3458 \pm 2,3454 \pm$ $1 \mathrm{Ma}$ ) extending as far eastwards as the Bamboo Creek Sector. Then, at $3446 \pm 5 \mathrm{Ma}$, the volcanic depocentre migrated to the Kitty's Gap volcano-sedimentary complex in the Coppin Gap Sector. Further east in the Bamboo Creek Sector, Panorama felsic volcanic rocks are absent, but at the corresponding stratigraphic level continental cross-bedded sandstone and shale have been preserved in a growth fault-controlled half-graben. Finally, at 3434 $\pm 5 \mathrm{Ma}$ the next younger depocentre is found in the northwestern segment of the NP Dome, and a still younger age of $3436 \mathrm{Ma}$ is reported $30 \mathrm{~km}$ to the NNE, outside the corridor map, (Van Kranendonk et al. 2001a, fig. 7). No dates are available from the outcrop on the NE flank of the Dome (Fig. 7), where DiMarco \& Lowe (1989) report palaeocurrent directions dominant to the NW and north, i.e. roughly parallel to the inferred slope direction of the Salgash Basin margin.

The transition from partial absence (silicified erosion surface) of the Panorama Fm in the Bamboo Creek Sector via intertidal conditions at Kittys Gap in the Coppin Gap Sector, and to relatively thick, silicified, well-sorted littoral (?) grainstones in the Gorge Range is interpreted as a basin-ward facies change (cf. De Vries et al. 2010), similar in orientation to the one in the Coongan Basin margin.

\section{Basin shape}

Although several superposed basin fill sequences can be recognized, it is remarkable that in the corridor map area the parameters defining the basin shape, such as the facing of the basin slope, do not change during deposition of the Warrawoona Group. This has been already mentioned tentatively in Nijman \& De Vries (2004). The growth fault vergence in the Coppin Gap Sector is eastwards and rotates via the Marble Bar Sector to northwards in the NP Dome. The zonation in growth fault architecture follows the same curved trend (indicated in light blue in Fig. 2). Our reconstructions point to a basin shape that was curved, with the centre or opening to the NW, rimmed by normal faults and with centripetal, downslope, gravitational mass transport by block rotation along listric faults, block glides over bedding-parallel shear zones, and frontal slumps (Fig. 9).

The traverse crosses the Coongan Basin margin from the proximal depocentre of Duffer volcanic rocks in the east to its distal pinch-out in the Antarctic Creek Member in the west. Where 
the growth fault pattern in the NP Dome and, as a consequence, the basin radius turns due north in the near absence of Duffer volcanic rock, the proximal zone might be expected further southwards beyond the limit of exposure of the NP Dome.

For the Salgash Basin the accumulation of Panorama Fm along the south side of the NP Dome suggests a position more proximal to the basin boundary than for the Coongan Basin.

\section{Adjacent basins?}

Further to the south and SE, in the greenstone belts surrounding the Shaw and Corunna Downs granitoid complexes, the southward vergence of the fault array in the Duffer Fm in the Coongan Belt ${ }^{7}$ and north-south extensional faults with indifferent vergence and dyke swarms in the Kelly Belt (Kloppenburg 2003, fig. 5.3) are not consistent with the proposed basin geometry in the traverse area. Also, the stratigraphical sequences in these areas show marked differences, especially for the felsic components with respect to those in the traverse map area: relatively young ages for the Panorama Fm (e.g. between $3433 \pm 2$ and $3427 \pm 2$ Ma, Van Kranendonk et al. 2001) and massive presence of the Wyman felsic volcanic sequence in the Kelly Belt; relatively old age of the Duffer Fm (between $3474 \pm 3$ and $3467 \pm 5$ Ma, GSWA database) and the occurrence of dolomite in the Coongan Belt (Zegers 1996); and a direct contact of Duffer and Panorama fms without intervening Apex Fm along the west side of the Shaw granitoid complex (Van Kranendonk 2000). Such differences may indicate the presence of one or more similar basins adjacent to those stacked along the North Pole-Bamboo Creek traverse. Long-lasting faults, such as the dextral transfer fault through the Warrawoona Belt (abandoned name), discussed above, may have played a role in basin separation and juxtaposition.

\section{Implications for the Palaeoarchaean cratonic evolution}

\section{How did it start?}

Much of the debate about the Archaean evolution of the Earth builds on assumptions about the composition and thickness of the evolving Palaeoarchaean crust, and the geodynamic processes behind it. It must be realized that what can be observed today are end products of Archaean crust, not the initial stages. Recorded Archaean crustal thickness varies between extremely thick $(>50 \mathrm{~km})$ like the one below the Dharwar craton in India (Gupta et al. 2013) or thin $( \pm 35 \mathrm{~km})$ as reported for the Pilbara by Yuan (2015) where the greenstone belts can be traced towards mid-crustal depths $(14 \mathrm{~km}$; Wellman 2000). Stankiewicz \& De Wit (2013, p. 675), however, state that the Moho now observed below Archaean cratons reflects very little of the original one, but is 'severely altered by tectonometamorphic and igneous processes, in many cases more than once, and cannot provide unequivocal data for geodynamic models dealing with secular changes in continental crust formation'. This limits the use of field-based studies in developing models for Palaeoarchaean crustal evolution.

The model of a very early Pilbara protocontinent above a mantle plume is based (Hickman 2012a): (1) on relatively small volumes of preserved old $(3.66-3.58 \mathrm{Ga})$ gneiss and $3.58 \mathrm{Ga}$ xenoliths of anorthosites within the granitoid complexes now exposed at the surface; (2) on the presence of detrital Zr crystals (max. age $3.72 \mathrm{Ga}$ ) within the Palaeo- and Mesoarchaean clastic sediments; and (3) on geochemical signatures, such as $\mathrm{Nd}$ and $\mathrm{Hf}$ isotopes (e.g. Amelin et al. 2000; Nebel et al. 2014). However, the available isotope data are

${ }^{7}$ We tend to uncouple the link, proposed by Zegers et al. (1996), between extension by growth faults in the Coongan Belt and east-over-west displacement in the Split Rock SZ along the east side of the Shaw granitoid complex. equivocal (Kemp et al. 2015) and much doubt remains about the existence of Eoarchaean continental crust, at least in the Pilbara.

As early as in the 1980s, following Sleep \& Windley (1982) and Bickle (1986), Vlaar (1986) and Hoffman \& Ranalli (1988) argued on theoretical geophysical arguments that the higher-temperature Archaean mantle must have resulted in a thick (up to $50 \mathrm{~km}$ ), hot, largely ductile mafic crust. The concept was further elaborated by geophysicists at Utrecht University (Vlaar et al. 1994): in a process resembling oceanic (mini-)subduction, fragments of the watercovered and therefore water-rich, thin, cooled and therefore brittle, upper part of the relatively hot and ductile crust are supposed to sink to its very bottom, thereby passing through an eclogitic stage (cf. Rapp et al. 2003; Laurie \& Stevens 2012). Delamination of the lower crust and dripping of eclogite into the somewhat lighter harzburgitic upper part of the asthenosphere then produced a local hotspot by decompression, in its turn generating an uprising bimodal tonalite-trondhjemite-granodiorite (TTG) and basalt melt. In our project, Zegers \& Van Keken (2001) and Kloppenburg (2003) considered Raleigh discontinuities at the crust-mantle boundary above a deeper mantle plume responsible for the delamination (cf. Johnson et al. 2014).

By now, a variety of models of Palaeoarchaean crustal development have been proposed. They are generally mantle plume-generated (Smithies et al. 2005; Van Kranendonk et al. 2015a), and/or imply mini-subduction and eclogite-dripping mechanisms (e.g. Foley et al. 2003; Fischer \& Gerya 2016). Fischer \& Gerya's $(2016$, fig. 12) thermodynamic plume-lid models have been run for a wide variety of initial crustal compositions and also incorporate mini-subduction and intracrustal convection. To what extent felsic components had played a role already in the Hadean or Eoarchaean crust (Sizova et al. 2010) largely depends on isotope-geochemical and petrological (e.g. comparison of $P T$-data with Phanerozoic PT-paths; Van Kranendonk et al. 2015a, fig. 5) arguments.

It is not the primary aim of this paper to address the initial stage of Eo- to Palaeoarchaean crustal evolution. This has already been done extensively by, amongst others, the authors referred to above. However, our findings in the East Pilbara may add to discussion about these scenarios in which top-down interpretations, i.e. from the original uppermost crustal levels towards depth, are relatively rare.

To that end we present a model for the Palaeo- to Mesoarchaean crustal evolution in the Pilbara in Figure 10.

\section{Hotspot generation by mini-subduction and eclogite dripping causing upper crustal extension}

Following the concepts of Hoffman and Vlaar, a mafic crust of $c$. $45 \mathrm{~km}$ thickness has been taken as a starting point (Fig. 10a). Two of the above-mentioned options have been illustrated: (1) a mantle plume with Raleigh discontinuities and (2) mini-subduction as initiators of (3) eclogite dripping. Mini-subduction, assisted by intracrustal convection (Fischer \& Gerya 2016; cf. Foley et al. 2003), might well be related to extension patterns by coolinginduced contraction at the very surface of the crust. The irregular non-simultaneous passive sinking of upper crustal slabs may be the primary cause for the distribution of relatively minor hotspots dispersed in place and time along the Moho and for basin formation of the size and shape suggested by our findings.

Where earthly analogues are not available for such a differently looking Hadean to Palaeoarchaean Earth, examples from neighbouring planets may be of help (Mège \& Ernst 2001). Previously, we compared the Archaean collapse basins not with Phanerozoic calderas but with the corona structures of Venus (further information in Nijman \& De Vries 2004; cf. Smrekar \& Stofan 1997; see also Gerya 2014; 2016) and pointed also at extensional 


\section{Paleo- to Mesoarchean crust and basin development}

\section{$<3.2 \mathrm{Ga}$}

\section{Sagduction $\left(D_{3}\right)$}

Formation of dome-and-keel geometry; rise of granitoid complexes and concurrent formation of progressive unconformities and huge influxes of siliciclastic sediment

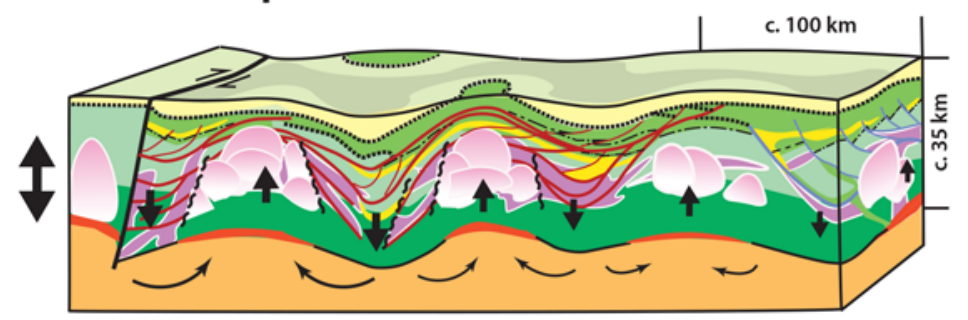

(e)

\section{3-3.2 Ga}

\section{Regional compression $\left(D_{2}\right)$}

(probably in two phases)

Crust has reached normal strength and reacts to SE-ward compressive stress generated by continental accretion; first appearance of regional unconformities and influx of clastic sediments. Synkinematic growth of granitoid complexes due to redistribution of mass and temperatures at the base of the crust

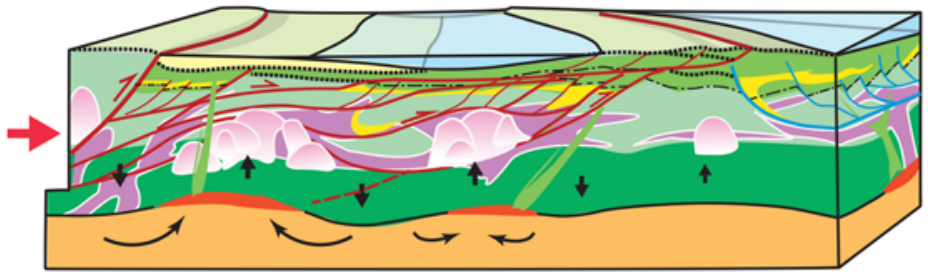

(d)

\section{3 - >3.5 Ga}

\section{Collapse basins $\left(D_{1}\right)$}

Development of mid crustal detachments accommodating prolonged extension at upper crustal levels, due to further collapse; (semi) circular dyke swarms; extensive synextensional TTG intrusion; formation of gneiss; redistribution of hot spots at crustal base.

Upon cooling the crustal arch collapses forming a basin predominantly filled by basalt from magma sources in the lower crust; boundary between brittle and ductile regime migrates downwards; of peridotite/gabbro sills.

N.B. the process of arching and collapse may have been recurrent
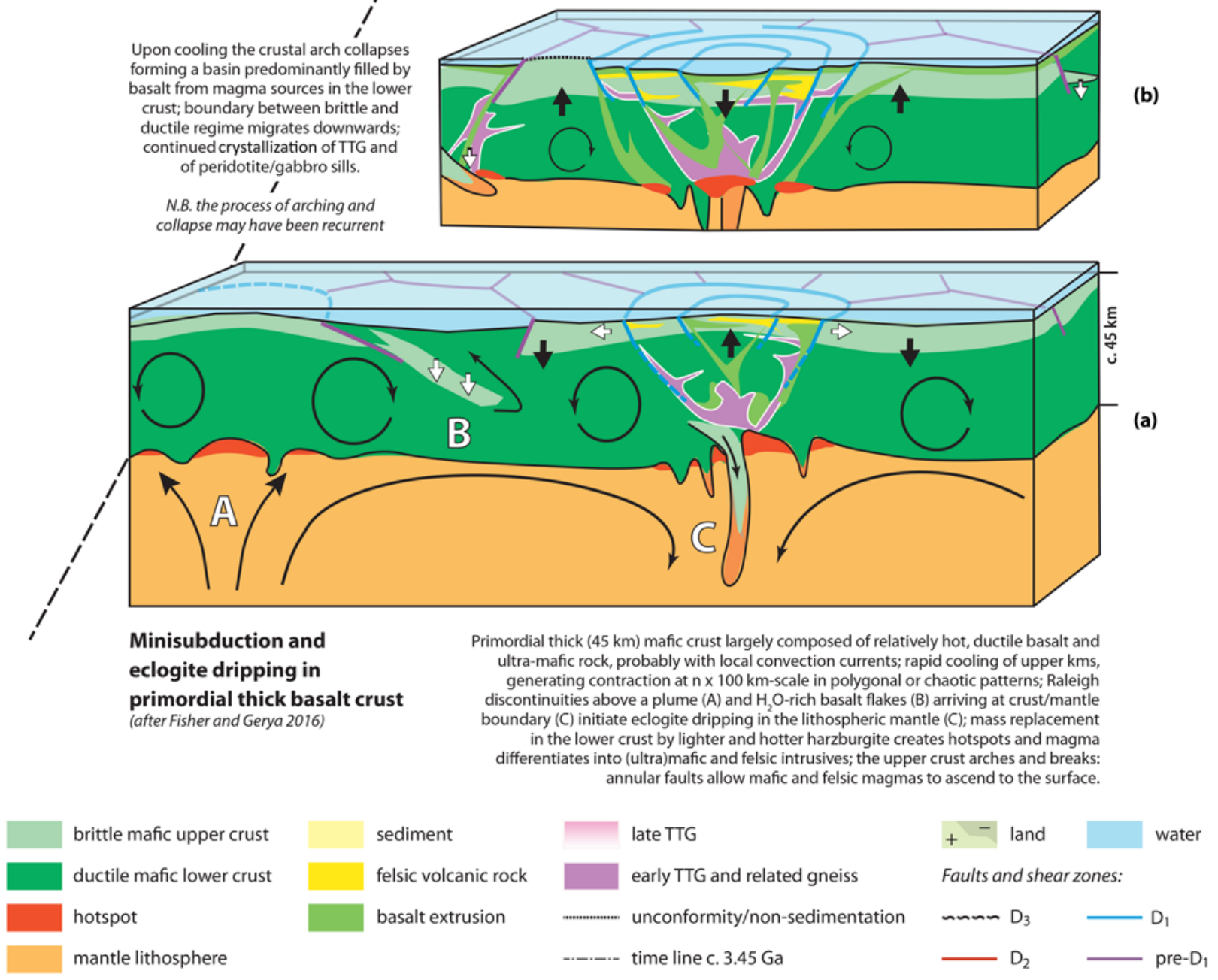

Fig. 10. Palaeo- to Mesoarchaean development of crust and basins. Explanation in figure and text. TTG, tonalite-trondhjemite-granodiorite. 
features in Martian chaos terranes described by Farmer (2000). To the latter, those in Noctis Labyrinthus at the northwestern rim of Solis Planum may be added (ESA, Mars Express, 28 January 2016, image taken on 15 July 2015: Supplementary material fig. h). This polygonal network extends over $1200 \mathrm{~km}$ in length, with individual polygons $^{8}$ in the order of $n \times 100 \mathrm{~km}$ in diameter; it is thought to result from crustal extension by kilometre-deep reaching faults.

\section{Vertical crustal movement, collapse basins and mid-crustal detachment}

The crustal collapse model proposed for the Early Archaean basins implies initial uplift from a, not necessarily deep, submarine level of deposition of pillowed flood basalt to above base level with development of extensional faults and fractures (Fig. 10b), followed by subsidence (Fig. 10c). It induced the regressive-transgressive sedimentary sequences we observed in volcano-sedimentary complexes in both Barberton and the Pilbara (De Vries et al. 2010). Since the growth-fault systems are of several superposed orders of magnitude, this may also be expected to be the case for the regressive-transgressive trends: local small-scale variations superposed upon the larger-scale phenomena, including the scale of superposed basin fills.

Subhorizontal shear zones might be expected where slope-related gravity-driven normal fault systems merge into an incompetent stratigraphic level. However, structures like the kilometre-thick amphibolite-grade ductile Mount Edgar SZ along the south side of the dome, and interpreted as mid-crustal detachment (Kloppenburg et al. 2001; Kloppenburg 2003), are not easily explained by this mechanism. The presence of $3426 \mathrm{Ma}$ old (E)NE-(W)SW extension structures (conjugate shear bands and stretching lineations) within gneisses of the SW sector of the Mount Edgar Dome and similarly parallel-orientated lineations in the entire Mt Edgar SZ (blue arrows in Fig. 4) are of Salgash age and definitely pre- $\mathrm{D}_{2}$. They do not correspond with the $\mathrm{D}_{1}$ extension directions near the Earth's surface at that time in the corridor map area. The succeeding $\mathrm{D}_{2}$ compression and $\mathrm{D}_{3}$ doming might have rotated and aligned older and ductile internal structures of the dome into a NE-SW orientation. Alternatively, the Mount Edgar SZ may have been situated outside the Salgash Basin margin, as it in fact still is, in an adjacent basin to the south where the same $\mathrm{D}_{1}$ extension directions occur (cf. section 'Adjacent basins?' above). However, the problem of disharmony between $\mathrm{D}_{1}$ orientations at the surface and at depth during the Palaeoarchaean needs future attention.

Nevertheless, supposing a still relatively shallow crustal position of the boundary between ductile and brittle deformation during the process of Archaean crustal cooling, shear zones related to arching above a shallow plume and sole detachments to gravity-driven normal fault arrays during the collapse phase may have merged with ductile crustal detachments, even interconnecting the extensional systems of adjacent basins.

\section{Thrusting to SE, coarse-clastic sedimentation and initiation of crustal overturn}

Figure 10d visualizes our conclusions with respect to a largely predome-and-keel compressive stress field in the Pilbara (cf. Fig. 8). From where did this force originate? At first thought, a relationship with continental accretion is obvious. The NE-SW trend of the accretionary boundaries of the Pilbara craton matches well with the $\mathrm{D}_{2}$ NW-SE compression. But, according to Hickman (2012a),

\footnotetext{
${ }^{8}$ Megapolygons on Mars are also related to cryogenic features of extraordinary large size although tectonic causes are not excluded (cf. McGill \& Scott Hills 1992). The ones here referred to are an order of size larger.
}

the collision of West and East Pilbara must be dated at c. $3050 \mathrm{Ma}$ which is by far too late to be directly connected with $\mathrm{D}_{2}$ compression. Beintema (2003, fig. 8.4) reports c. $3265-3150 \mathrm{Ma}$ subduction activity, supposed to have taken place to the NW beyond West Pilbara, which created a NW-SE compressive stress field along the proto-Sholl Shear Zone. This matches with the $c .3 .19 \mathrm{Ga}$ timing of the Regal thrust, causing obduction of oceanic crust upon the Karratha Terrane of West Pilbara (Hickman 2012a).

By the time the craton started to grow, the cooling of the Palaeoarchaean crust must have progressed, resulting in gradually downward migration of the brittle-ductile boundary and continentalization of the crust by TTG intrusion towards a stage, allowing for

(1) the transfer of stress to an extent that NW-over-SE shear deformation could take place;

(2) the initiation of a ramp-and-flat thrust system, in many places facilitated by pre-existing bedding-parallel $D_{1}$ detachments.

\section{$D_{3}$ dome-and-belt formation}

Collins et al.'s (1998) crustal turnover model is encountered in the final $\mathrm{D}_{3}$ stage of the Archaean crust generating the present-day dome-and-belt pattern (Fig. 10e), and the development of shear zones mainly along the southern side of the domes (e.g. Muccan and Mt Edgar SZs). This pattern, though resulting from gravitational instability, appears to have been triggered by regional $\mathrm{D}_{2}$ compression. It may have caused a first Raleigh instability leading to an egg-box pattern of sinking greenstones around doming TTG. The takeover of $\mathrm{D}_{2}$ thrusting by $\mathrm{D}_{3}$ crustal turnover and its relative timing (namely following the $3.19 \mathrm{Ga}$ deposition of the Nimingarra BIF) are most explicitly illustrated by the growth of the Bamboo Creek Syncline and its progressive infilling with sometimes very coarse clastic material and basalt (cf. section 'Pre- to syndoming character of $\mathrm{D}_{2}$ ' above). The process lasted until at least c. $2.9 \mathrm{Ga}$.

\section{Conclusions}

(1) The sequential restoration of a $100 \mathrm{~km}$ long traverse through East Pilbara results in the recognition of two, and possibly four, superposed volcano-sedimentary basins within the Palaeoarchaean Warrawoona Group. The basin fills encompass time intervals of respectively c. $25 \mathrm{Ma}$ for the Talga Talga Subgroup, c. 9 Ma for the Coongan Basin, c. $26 \mathrm{Ma}$ for the Salgash Basin and $>30 \mathrm{Ma}$ for the Euro Basalt. The Coongan and Salgash basin margin architecture is defined by lateral facies changes (Duffer Fm $\leftrightarrow$ Mt Ada Basalt; Panorama Fm/Strelley Pool Chert volcano-sedimentary complex $\leftrightarrow$ Apex and Euro Basalts) and by structural control by superposed growth-fault arrays. The latter have a systematic and persistent basincentre orientation, which from east to west within the traverse corridor turns gradually from due west to due north, thereby defining a curved basin outline. The boundary between the Coongan and Salgash basins appears to be time-transgressive towards the east, with indications of sedimentary reworking (former Towers Fm, in particular the Marble Bar Chert (Coltice et al. 2012)); but our interpretation of eastwards onlap needs further confirmation by more detailed dating and facies analysis.

(2) The basin configuration is not one of 'small sedimentary basins' under a regime of 'low-grade metamorphism driven by heat from granite doming that was synchronous with basin deformation' (Van Kranendonk et al. 2015a, p. 89), but represents a major characteristic an order of magnitude larger than that of the now visible dome-andbelt geometry and preceding it; it demands a suitable 
geodynamic explanation at appropriate scale, for (a) the basin size (basin radius of over $100 \mathrm{~km}$ ), (b) the nonlinear shape, (c) the stationary position and orientation during basin superposition, (d) the pulsating character of the basin-forming process and (e) the abrupt change in orientation and infilling of adjacent basins.

(3) As to the shape, size and fill of the basin(s), our previously proposed collapse basin model (Nijman \& De Vries 2004) is corroborated and extended by the newly presented evidence. It provides for initial uplift from overall submarine deposition of pillowed flood/plateau basalt to around base level, with development of synsedimentary extensional fault systems superposed upon each other in different orders of magnitude, and accompanied by fractures, dyke swarms and widespread slump folding. The opening of the crust by arching facilitated the extrusion of bimodal volcanic rocks, which filled the basin during collapse of the crustal uplift. The uplift is thought to have been generated above a local hotspot at the base of the Palaeoarchaean crust, in the East Pilbara stationary during deposition of the Warrawoona Group. In our 2004 model, however, we did not yet account for the rhythmicity shown in the basin superposition. Fischer \& Gerya's (2016) plume-lid thermodynamic model, in which basin formation and accumulation of lava and sediment seal the plume effect and renew the process of eclogite dripping, offers a possibly good explanation for both the rhythmicity and asymmetry in the basin fill sequences. Another option for the superposition of basins might be the influence of orbital-forced cyclicity on the basin-forming process.

(4) At c. $3.31 \mathrm{Ga}, \mathrm{NW}-\mathrm{SE}$ compression takes over from extension, often with reversal of sense of translation along pre-existing structures. Evidence for the $\mathrm{D}_{2}$ phase is widespread and consists of ramp-and-flat thrusting, with emphasis on long flats and ramps with thrust imbrication only in places of obstruction of the mass transfer. In the NP Dome bulk (N)W-over-(S)E shear accompanied this deformation. The $\mathrm{D}_{2}$ shortening is estimated to amount to $c .14 \%$. It occurred between just before the $3314 \mathrm{Ma}$ intrusion of the Coppin Gap Granodiorite Suite and the end of deposition of the $c$. $3.19 \mathrm{Ga}$ (see footnote 5) Nimingarra BIF, probably in two phases concurrent with synkinematic granite intrusions in the Mt Edgar Dome.

(5) At about $3.2 \mathrm{Ga}$, the deposition changed drastically from predominantly volcanic to predominantly clastic (cf. Zegers et al. 1998; Dhuime et al. 2012). This process occurred in two stages, both accompanied by unconformities. The first stage coincides with the $c$. $3.19 \mathrm{Ga}$ deposition of the quartz-arenite-based Nimingarra BIF and with the aftermath of $\mathrm{D}_{2}$ compression. The second stage starts at $c .3 .00 \mathrm{Ga}$ with the coarse clastic sediments of the De Grey Supergroup as an answer to preceding $\mathrm{D}_{2}$ compression-related uplift. Progressive unconformities prove that this stage was coeval with the $\mathrm{D}_{3}$ dome-and-belt formation, culminating at around $2.9 \mathrm{Ga}$.

(6) The change from an extension- to a compressiondominated regime marks the transition from an, as yet, still poorly known but much discussed crustal architecture and deformation mechanism, towards the better-known plate-driven tectonics (continental accretion) with the associated accumulation of clastic sedimentary assemblages. Van Kranendonk et al. (2015b) present evidence of a global increase in plate-driven crustal recycling at $3.2 \mathrm{Ga}$ on the basis of a rise in $\delta \mathrm{O}^{18}$ values in zircon crystals. In our model, plate-driven tectonics start c. $3.31 \mathrm{Ga}$ ago and the change around $3.2 \mathrm{Ga}$ then coincides with the overlapping end of the compression (c. $3.19 \mathrm{Ga}$ ) and start of the dome-and-belt formation. The $\mathrm{D}_{2}$ compression is considered to have triggered the domeand-belt formation and should be accounted for in models of Palaeoarchaean crustal evolution in the Pilbara.

Acknowledgements This paper could not have been written without the effort of many colleagues and students during more than two decades of our Pilbara and Earth Earliest Basins projects. In particular, we mention colleagues involved in its organization, in the fieldwork or in discussing results: the late Peter Ypma, Stan White, Jan Wijbrans, Kim Hein, Poppe de Boer, Frances Westall, Hanan Kisch, Manfred van Bergen, Paul Mason, Pieter Vroon, Maarten de Wit, Cees Passchier, Paul Dirks and Frank Beunk; and within the Australian geological community: Richard Blewett, Andrew Glikson, Arthur Hickman, Dave Nelson and Martin Van Kranendonk. We thank Onno Houtzager for his enthusiastic participation in our 2013 field trip. The important contribution of $\mathrm{PhD}$ students from 1994 until 2008, with Tanja Zegers as a pioneer, has already been mentioned in the introduction to this article. However, the investigation of key areas within the corridor map of this paper also relied on the work of many MSc students: for the stereoplots and maps of key areas along the traverse we used the data of Wouter Smits, Reinier Pieters, Fons Marcelis, Marc Goossens, and Rens Verburg in the Bamboo Creek Sector as early as in 1985/86; and, between 1992 and 2002: Bart Willigers, Albert Krikke, Tjirk Benedictus, Sander van den Boorn, Ivo Vos and Karin Louzada in the Coppin Gap Sector and Gorge Range; Willem-Maarten van Haaften in the Marble Bar Sector; Karen de Bruijne and Mariëlle Valkering in the North Pole Dome. At Utrecht University we gratefully acknowledge Alexander Prent for his assistance in organizing our geochron database and Margot Stoete for preparing the figures for print. Finally, our thanks go to the anonymous reviewers of the manuscript of this paper.

Funding Through many years, the project benefited from the financial support of the Dutch Dr Schürmann Foundation. Grant no. 93/2013 facilitated the fieldwork needed to complete our data along the East Pilbara traverse.

\section{Scientific editing by Graham Shields-Zhou}

Correction notice: Figures 2 and 3 as well as supplementary files c and d have been updated. The reference Nelson 1999 has been updated to Nelson 1998.

\section{References}

Allmendinger, R.W., Cardozo, N. \& Fisher, D. 2012. Structural Geology Algorithms: Vectors and Tensors. Cambridge University Press, Cambridge, UK

Amelin, Y., Lee, D.-C. \& Halliday, A.N. 2000. Early-middle Archaean crusta evolution deduced from $\mathrm{La}-\mathrm{Hf}$ and $\mathrm{U}-\mathrm{Pb}$ isotopic studies of single zircon grains. Geochimica et Cosmochimica Acta, 64, 4205-4225.

Arndt, N.T. 1999. Why was flood volcanism on submerged continental platforms common in the Precambrian. Precambrian Research, 97, 155-164.

*Beintema, K.A. 2003. Geodynamic evolution of the West and Central Pilbara Craton in Western Australia: A mid-Archaean active continental margin. $\mathrm{PhD}$ thesis, Utrecht University, the Netherlands. Geologica Ultraiectina, 232, available from the Faculty of Geosciences and as Open Source document through NARCIS - National Academic Research and Collaborations Information System, http://dspace.library.uu.nl/handle/1874/267998

Bickle, M.J. 1986. Implications of melting for stabilization of the lithosphere and heat loss in the Archaean. Earth and Planetary Science Letters, 80, 314-323.

Bickle, M.J., Bettenay, L.F., Boultier, C.A., Groves, D.L. \& Morant, P. 1980 Horizontal tectonic interaction of an Archaean gneiss belt and greenstones, Pilbara block, Western Australia. Geology, 8, 525-529.

Blewett, R.S. 2002. Archaean tectonic processes: a case for horizontal shortening in the North Pilbara Granite-Greenstone Terrane, Western Australia. Precambrian Research, 113, 87-120.

Blewett, R.S., Wellman, P., Ratajkoski, M. \& Huston, D.L. 2000. Atlas of North Pilbara Geology 1:1.5 Million Scale. Australian Geological Survey Organisation, Record 2000/4.

Blewett, R.S., Shevchenko, S. \& Bell, B. 2004. The North Pole Dome: a nondiapiric dome in the Archaean Pilbara Craton, Western Australia Precambrian Research, 133, 105-120.

Boulter, C.A., Bickle, M.J., Gibson, B. \& Wright, R.K. 1987. Horizontal tectonics pre-dating upper Gorge Creek Group sedimentation, Pilbara Block Western Australia. Precambrian Research, 36, 241-225.

Buick, R., Thornett, J.R., McNaughton, N.J., Smith, J.B., Barley, M.E. \& Savage, M. 1995. Record of an emergent continental crust $\sim 3.5$ billion years ago in the Pilbara Craton of Australia. Nature, 375, 574-577.

Byerly, G., Lowe, D.R., Wooden, J.L. \& Xiaogang, X. 2002. An Archean impact layer from the Pilbara and Kaapvaal Cratons. Science, 297, 1325-1327.

Cardozo, N. \& Allmendinger, R.W. 2013. Spherical projections with OSXStereonet. Computers \& Geosciences, 51, 193-205, https://doi.org/10. 1016 /j.cageo.2012.07.021 
Collins, W.J. 1989. Polydiapirism of the Archaean Mt. Edgar batholith, Pilbara Block, Western Australia. Precambrian Research, 43, 41-62.

Collins, W.J., Van Kranendonk, M.J. \& Teyssier, C. 1998. Partial convective overturn of Archaean crust in the east Pilbara Craton, Western Australia: driving mechanisms and tectonic implications. Journal of Structural Geology, 20, 1405-1424.

Coltice, N., Flament, N., Rey, P. \& Sauvestre, R. 2012. A deep subaqueous fan depositional model for the Palaeoarchaean (3.46 Ga) Marble Bar Cherts, Warrawoona Group, Western Australia. Geological Magazine, 149, 743-749, https://doi.org/10.1017/S0016756812000131

*De Vries, S.T. 2004. Early Archaean sedimentary basins: depositional environment and hydrothermal systems. Examples from the Barberton and Coppin Gap Greenstone Belts. PhD thesis, Utrecht University, the Netherlands. Geologica Ultraiectina, 244, available from the Faculty of Geosciences and as Open Source document through NARCIS, https://dspace. library.uu.nl/handle/1874/1155

*De Vries, S.T., Nijman, W., Wijbrans, J.R. \& Nelson, D.R. 2006. Stratigraphic continuity and early deformation of the central part of the Coppin Gap Greenstone Belt, Pilbara, Western Australia. Precambrian Research, 147, $1-27$.

*De Vries, S.T., Nijman, W. \& De Boer, P.L. 2010. Sedimentary geology of the Palaeoarchaean Buck Ridge (South Africa) and Kittys Gap (Western Australia) volcano-sedimentary complexes. Precambrian Research, 183, 749-769.

De Wit, M.J. 1982. Gliding and overthrust nappe tectonics in the Barberton greenstone belt. Journal of Structural Geology, 4, 117-136.

De Wit, M.J. 1998. On Archean granites, greenstones, cratons, and tectonics: does the evidence demand a verdict? Precambrian Research, 91, 181-226.

De Wit, M.J., Furnes, H. \& Robins, B. 2011. Geology and tectonostratigraphy of the Onverwacht Suite, Barberton Greenstone Belt, South Africa. Precambrian Research, 186, 1-27.

Dhuime, B., Hawkesworth, C. J., Cawood, P. A. \& Storey, C. D. 2012. A change in the geodynamics of continental growth 3 Billion years ago. Science, $\mathbf{3 3 5}$, $1334-1336$.

DiMarco, M.J. \& Lowe, D.R. 1989. Stratigraphy and sedimentology of an early Archean felsic volcanic sequence, Eastern Pilbara Block, Western Australia, with special reference to the Duffer Formation and implications for crustal evolution. Precambrian Research, 44, 147-169.

Farmer, J.D. 2000. Hydrothermal systems: doorways to early biosphere evolution. GSA Today, 10, 1-9.

Fischer, R. \& Gerya, T.V. 2016. Early Earth plume-lid tectonics: A high-resolution 3D numerical modelling approach. Journal of Geodynamics, 100, 198-214, https://doi.org/10.1016/j.jog.2016.03.004

Foley, S.F., Buhre, S. \& Jacob, D.E. 2003. Evolution of the Archaean crust by lamination and shallow subduction. Nature, 421, 249-252.

Gerya, T.V. 2014. Plume-induced crustal convection: 3D thermomechanical model and implications for the origin of novae and coronae on Venus. Earth and Planetary Science Letters, 391, 183-192.

Gerya, T.V. 2016. What was before plate tectonics?, 'Speaking of Geoscience', Geological Society of America guest blog, 16 April 2016, http://wp.me pNy1x-wV [last accessed 7 May 2017].

Glikson, A.Y. \& Vickers, J. 2010. Asteroid impact connections of crustal evolution Australian. Journal of Earth Sciences, 57, 79-95.

Glikson, A.Y., Hickman, A.H., Evans, N.J. \& Romano, S.S. 2016. A new 3.46 Ga asteroid impact ejecta unit at Marble Bar, Pilbara Craton, Western Australia: A petrological, microprobe and laser ablation ICPMS study. Precambrian Research, 279, 103-122.

Gupta, S., Rai, S., Prakasam, K.S. \& Gaur, V.K. 2013. First evidence for anomalous thick crust beneath mid-Archean western Dharwar craton. Current Science, 84, 1219-1226.

Hamilton, W. 1998. Archean magmatism and deformation were not products of plate tectonics. Precambrian Research, 91, 143-179.

Hickman, A.H. 1977. New and revised definitions of rock units in the Warrawoona Group, Pilbara Block. GSWA Annual Report, 1976.

Hickman, A.H. 1983. Geology of the Pilbara Block and its environs. Western Australia Geological Survey Bulletin, 127.

Hickman, A.H. 2004. Two contrasting granite-greenstone terranes in the Pilbara Craton, Australia: evidence for vertical and horizontal tectonic regimes prior to 2900 Ma. Precambrian Research, 131, 153-172.

Hickman, A.H. 2008. Regional review of the 3426-3350 Ma Strelley Pool Formation, Pilbara Craton, Western Australia. GSWA Record, 2008/15, 1-27.

Hickman, A.H. 2011. Pilbara Supergroup of the East Pilbara Terrane, Pilbara Craton: Updated lithostratigraphy and comments on the influence of vertical tectonics. GSWA Annual Review, 2009-10, 50-59.

Hickman, A.H. 2012a. Review of the Pilbara Craton and Fortescue Basin, Western Australia: Crustal evolution providing environments for life. Island Arc, 21, 1-31.

Hickman, A.H. 2012b. North Shaw, W.A. Sheet 2755. 2nd edn. Western Australian Geological Survey 1:100 000 Geological Series, Perth.

Hickman, A.H. \& Van Kranendonk, M.J. 2008. Marble Bar, W.A. Sheet 2955 Western Australian Geological Survey 1:100 000 Geological Series, Perth.

Hickman, A.H. \& Van Kranendonk, M.J. 2012. Early Earth evolution: Evidence from the 3.5-1.8 Ga geological history of the Pilbara region of Western Australia. Episodes, 35, 283-297.

Hoffman, P.F. \& Ranalli, G. 1988. Archaean flake tectonics. Geophysical Research Letters, 15, 1077-1080.
Johnson, T.E., Brown, M., Kaus, B.J.P. \& VanTongeren J.A. 2014. Delamination and recycling of Archaean crust caused by gravitational instabilities. Nature Geoscience, 7, 47-52.

Kemp, A.I.S., Hickman, A.H., Kirkland, C.L. \& Vervoort, J.D. 2015. Hf isotopes in detrital and inherited zircons of the Pilbara Craton provide no evidence for Hadean continents. Precambrian Research, 261, 112-126.

Kitajima, K., Hirata, T., Maruyama, S., Yamanashi, T., Sano, Y. \& Liou, J.G. 2008. U-Pb zircon geochronology using LA-ICP-MS in the North Pole Dome, Pilbara Craton, Western Australia: a new tectonic growth model for the Archean chert/greenstone succession. International Geology Review, 50, 1-14, https://doi.org/10.2747/0020-6814.50.1.1

*Kloppenburg, A. 2003. Structural evolution of the Marble Bar Domain, Pilbara granite-greenstone terrain, Australia: The role of Archaean mid-crustal detachments. PhD thesis, Utrecht University, the Netherlands. Geologica Ultraiectina, 237, available from the Faculty of Geosciences and as Open Source document through NARCIS, http:/dspace.library.uu.nl/handle/1874/ 32142

*Kloppenburg, A., White, S.H. \& Zegers, T.E. 2001. Structural evolution of the Warrawoona Greenstone Belt and adjoining granitoid complexes, Pilbara Craton, Australia: implications for Archaean tectonic processes. Precambrian Research, 112, 107-147.

Kusky, T.M., Polat, A. et al. 2016. Insights into the tectonic evolution of the North China Craton through comparative tectonic analysis: A record of outward growth of Precambrian continents. Earth-Science Reviews, 162, $387-432$.

Laurie, A. \& Stevens, G. 2012. Water-present eclogite melting to produce Earth's early felsic crust. Chemical Geology, 314-317, 83-95.

Lowe, D.H. 1983. Restricted shallow-water sedimentation of early Archean stromatolitic and evaporitic strata of the Strelley Pool Chert, Pilbara Block, Western Australia. Precambrian Research, 19, 239-283.

Mandl, G. \& Crans, W. 1981. Gravitational gliding in deltas. In: McCLay, K.R. \& Price, N.J. (eds) Thrust and Nappe Tectonics. Geological Society, London, Special Publications, 9, 41-54, https://doi.org/10.1144/GSL.SP.1981.009.01. 05

*Marcelis, A.H.M. 1986. Geology of the Bamboo Creek greenstone belt, Pilbara Block, Western Australia. MSc thesis (unpublished), Department of Structural and Applied Geology, Utrecht University (in cooperation with Bamboo Creek Management Pty. Ltd.).

Mauduit, T. \& Brun, J.P. 1998. Growth fault/rollover systems: Birth, growth and decay. Journal of Geophysical Research, 103, 18.119-18.136.

McCall, G.J.H. 2003. A critique of the analogy between Archaean and Phanerozoic tectonics based on regional mapping of the MesozoicCenozoic plate convergent zone in the Makran, Iran. Precambrian Research, 127, 5-17.

McGill, G.E. \& Scott Hills, I. 1992. Origin of giant Martian polygons. Journal of Geophysical Research, 97, 2633-2647.

Mège, D. \& Ernst, R.E. 2001. Contractional effects of mantle plumes on Earth, Mars, and Venus. In: Ernst, R.E. \& Buchan, K.I. (eds) Mantle Plumes and their Identification Through Time. Geological Society of America Special Papers, 352, 103-140.

Nebel, O., Campbell, H., Sossi, P.A. \& Van Kranendonk, M.J. 2014. Hafnium and iron isotopes in early Archaean komatiites record a plume-driven convection cycle in Hadean Earth. Earth and Planetary Science Letters, 397, 111-120.

Nelson, D.R. 1998. Compilation of SHRIMP U-Pb zircon geochronology data. GSWA Record 1998/2.

Nijman, W. 1998. Cyclicity and basin axis shift in a piggyback basin: towards modelling of the Eocene Tremp-Ager Basin, South Pyrenees, Spain. In: Mascle, A., Puigdefabregas, C., Luterbacher, H.P. \& Fernandez, M. (eds) Cenozoic Foreland Basins of Western Europe. Geological Society, London, Special Publications, 134, 135-162, https://doi.org/10.1144/GSL.SP.1998.134.01.07

*Nijman, W. \& De Vries, S.T. 2004. Early Archaean crustal collapse structures and sedimentary basin dynamics. In: Eriksson, P.G., Altermann, W., Nelson, D.R., Mueller, W.U. \& Catuneanu, O. (eds) The Precambrian Earth: Tempos and Events. Developments in Precambrian Geology, 12. Elsevier, Amsterdam, 139-155.

*Nijman, W., De Bruijne, C.H. \& Valkering, M.E. 1998/99a. Growth fault control of Early Archaean cherts, barite mounds and chert-barite veins, North Pole Dome, Eastern Pilbara, Western Australia. Precambrian Research, 95, 247-274 (erratum re-edition of Precambrian Research, 88, 25-52, 1998).

*Nijman, W., Willigers, B.J.A. \& Krikke, A. 1998/99b. Tensile and compressive growth structures: relation between sedimentation, deformation and granite intrusion in the Archaean Coppin Gap Greenstone belt, Eastern Pilbara, Western Australia. Precambrian Research, 95, 277-302 (erratum re-edition of Precambrian Research, 88, 83-107, 1998).

* Nijman, W., Clevis, Q. \& De Vries, S.T. 2010. The waning stage of a greenstone belt: the Mesoarchaean Mosquito Creek Basin of the East Pilbara, Western Australia. Precambrian Research, 180, 251-271.

Oliver, N.H.S. \& Cawood, P.A. 2001. Early tectonic dewatering and brecciation on the overturned sequence at Marble Bar, Pilbara Craton, Western Australia: dome-related or not? Precambrian Research, 105, 1-15.

Orberger, B., Rouchon, V., Westall, F., De Vries, S.T., Wagner, C. \& Pinti, D.L. 2006. Microfacies and origin of some Archean cherts (Pilbara, Australia). In: Reimold, W.U. \& Gibson, R.L. (eds) Processes on the Early Earth. Geological Society of America Special Papers, 405, 133-156. 
Rapp, R.P., Shimizu, N. \& Norman, M.D. 2003. Growth of early continental crust by partial melting of eclogite. Nature, 425, 605-609.

Sheppard, S., Krapeža, B., Zi, J.-W., Rasmussen, B. \& Fletcher, I. 2017. SHRIMP U-Pb zircon geochronology establishes that banded iron formations are not chronostratigraphic markers across Archean greenstone belts of the Pilbara Craton. Precambrian Research, 292, 290-304.

Sinclair, H.D., Coackley, B.J., Allen, P.A. \& Watts, A.B. 1991. Simulation of foreland basin stratigraphy using a diffusion model of mountain belt uplift and erosion: an example from the central Alps, Switzerland. Tectonics, 10, 599-620.

Sizova, E., Gerya, T., Brown, M. \& Perchuk, L. 2010. Subduction styles in the Precambrian: Insight from numerical experiments. Lithos, 116, 209-229.

Sleep, N.H. \& Windley, B.F. 1982. Archaean plate tectonics: constraints and inferences. Journal of Geology, 90, 363-379.

*Smits, W. 1985. Greenstone belt geology and mineralisation at Bamboo Creek, Western Australia. MSc thesis (unpublished), Department of Structural and Applied Geology, Utrecht University (in cooperation with Bamboo Creek Management Pty. Ltd.).

Smithies, R. H., Van Kranendonk, M. J. \& Champion, D. C. 2005. It started with a plume - early Archaean basaltic proto-continental crust. Earth and Planetary Science Letters, 238, 284-297.

Smrekar, S.E. \& Stofan, E.R. 1997. Corona formation and heat loss on Venus by coupled upwelling and delamination. Science, 277, 1289-1294.

Stankiewicz, J. \& De Wit, M.J. 2013. 3.5 billion years of reshaped Moho, southern Africa. Tectonophysics, 609, 675-689, https://doi.org/10.1016/j. tecto.2013.08.033

*Strik, G.H.M.A. 2004. Paleomagnetism of late Archaean flood basalt terrains: implications for early Earth geodynamics and geomagnetism. $\mathrm{PhD}$ thesis, Utrecht University, the Netherlands. Geologica Ultraiectina, 242, available from the Faculty of Geosciences and as Open Source document through NARCIS, http://dspace.library.uu.nl/handle/1874/1574

Sztanó, O. \& De Boer, P.L. 1995. Basin dimensions and morphology as controls on amplification of tidal motions (the Early Miocene North Hungary Bay). Sedimentology, 42, 665-682.

Thorpe, R.I., Hickman, A.H., Davis, D.W., Mortensen, J.K. \& Trendall, A.F. 1992. $\mathrm{U} / \mathrm{Pb}$ zircon geochronology of Archaean felsic units in the Marble Bar region, Pilbara Craton, Western Australia. Precambrian Research, 56, 169-189.

*Van den Boorn, S.H.J.M. 2008. Silicon isotopes and the origin of Archaean cherts. PhD thesis, Utrecht University, the Netherlands. Geologica Ultraiectina, 293, available from the Faculty of Geosciences and as Open Source document through NARCIS, http://dspace.library.uu.nl/handle/1874/31228

*Van den Boorn, S.H.J.M., Van Bergen, M.J., Nijman, W. \& Vroon, P.Z. 2007. Dual role of seawater and hydrothermal fluids in Early Archean chert formation: Evidence from silicon isotopes. Geology, 35, 939-942.

*Van Haaften, W.M. \& White, S.H. 1998. Evidence for multiphase deformation in the Archean basal Warrawoona Group in the Marble Bar area, East Pilbara, Western Australia. Precambrian Research, 88, 53-66.

Van Hunen, J. \& Moyen, J-F. 2012. Archean subduction: Fact or fiction? Annual Review of Earth and Planetary Science, 40, 195-219.

Van Kranendonk, M.J. 1999. North Shaw, W.A. Sheet 2755. Western Australian Geological Survey 1:100 000 Geological Series, Perth.

Van Kranendonk, M.J. 2000. Geology of the North Shaw 1:100 000 Sheet. Geological Survey of Western Australia (GSWA) 1:100 000 Geological Series Explanatory Notes, Perth.

Van Kranendonk, M.J. 2004. Coongan, W.A. Sheet 2856. Western Australian Geological Survey 1:100 000 Geological Series, Perth.

Van Kranendonk, M.J. 2010a. Two types of Archean continental crust: plume and plate tectonics on Early Earth. American Journal of Science, 310, $1187-1209$

Van Kranendonk, M.J. 2010b. Geology of the Coongan 1:100 000 Sheet. Geological Survey of Western Australia (GSWA) 1:100 000 Geological Series Explanatory Notes, Perth.

Van Kranendonk, M.J., Hickman, A.H., Williams, I.R. \& Nijman, W. $2001 a$. Archaean Geology of the East Pilbara Granite-Greenstone Terrane, Western Australia - A Field Guide. GSWA Record 2001/9.

Van Kranendonk, M.J., Hickman, A.H. \& Collins, W.J. 2001b. Comment on 'Evidence for multiphase deformation in the Archean basal Warrawoona Group in the Marble Bar area, East Pilbara, Western Australia' by Van Haaften, W.M., White, S.H., Precambrian Research, 88, 53-66. Precambrian Research, 105, 73-78.
Van Kranendonk, M.J., Collins, W.J., Hickman, A.H. \& Pawley, M.J. 2004 Critical tests of vertical vs horizontal tectonic models for the Archaean East Pilbara Granite-Greenstone Terrane, Pilbara Craton, Western Australia. Precambrian Research, 131, 173-211.

Van Kranendonk, M.J., Hickman, A.H., Smithies, R.H., Williams, I.R., Bagas, L. \& Farrell, T.R. 2006. Revised Lithostratigraphy of Archean Supracrustal and Intrusive Rocks in the Northern Pilbara Craton, Western Australia. GSWA Record 2006/15.

Van Kranendonk, M.J., Smithies, R.H., Hickman, A.H. \& Champion, D.C. 2007. Review: secular tectonic evolution of Archean continental crust: interplay between horizontal and vertical processes in the formation of the Pilbara Craton, Australia. Terra Nova, 19, 1-38.

Van Kranendonk, M.J., Smithies, H.R. et al. 2015a. Making it thick: A volcanic plateau origin of Palaeoarchean continental lithosphere of the Pilbara and Kaapvaal cratons. In: Roberts, N.M.W., Van Kranendonk, M.J., Parman, S., Shirey, S. \& Clift, P.D. (eds) Continent Formation Through Time. Geological Society, London, Special Publications, 389, 83-111, https://oi.org/10.1144/ SP389.12

Van Kranendonk, M.J., Kirkland, C.L. \& Cliff, J. 2015b. Oxygen isotopes in Pilbara Craton zircons support a global increase in crustal recycling at $3.2 \mathrm{Ga}$. Lithos, 228-229, 90-98.

Vlaar, N.J. 1986. Archaean global dynamics. Geologie en Mijnbouw, 65, 91-101.

Vlaar, N.J., Van Keken, P.E. \& Van den Berg, A.P. 1994. Cooling of the Earth in the Archaean: consequences of pressure-release melting in a hotter mantle. Earth and Planetary Science Letters, 121, 1-18.

Wellman, P. 2000. Upper crust of the Pilbara Craton, Australia; 3D geometry of a granite/greenstone terrain. Precambrian Research, 104, 175-186.

*Westall, F., De Vries, S.T. et al. 2006. The 3446 Ga 'Kitty's Gap Chert', an early Archean microbial ecosystem. In: Reimold, W.U. \& Gibson, R.L. (eds) Processes on the Early Earth. Geological Society of America Special Papers, 405, 105-131.

Wiemer, D., Schrank, C.E., Murphy, D.T. \& Hickman, A.H. 2016 Lithostratigraphy and structure of the early Archaean Doolena Gap greenstone belt, East Pilbara Terrane, Western Australia. Precambrian Research, 282, $121-138$.

Williams, I.R. 1998. Muccan, W.A. Sheet 2956. Western Australian Geological Survey 1:100 000 Geological Series, Perth.

Williams, I.R. 1999. Geology of the Muccan 1:100 000 Sheet. Geological Survey of Western Australia (GSWA) 1:100 000 Geological Series Explanatory Notes, Perth.

Williams, I.R. \& Bagas, L. 2007a. Mount Edgar, W.A. Sheet 295., Western Australian Geological Survey 1:100 000 Geological Series, Perth.

Williams, I.R. \& Bagas, L. 2007b. Geology of the Mount Edgar 1:100 000 Sheet Geological Survey of Western Australia (GSWA) 1:100 000 Geological Series Explanatory Notes, Perth

Wingate, M.T.D., Kirkland, C.L., Bodorkos, S., Van Kranendonk, M.J. \& Hickman, A.H. 2011. 160958: volcaniclastic metasandstone, Trendall Reserve. Geochronology Record 1070. Geological Survey of Western Australia, 6.

Yuan, H. 2015. Secular change in Archaean crust formation recorded in Western Australia. Nature Geoscience, 8, 808-815.

*Zegers, T.E. 1996. Structural, kinematic and metallogenic Evolution of selected domains of the Pilbara granite-greenstone terrain; Implications for midArchean tectonic regimes. $\mathrm{PhD}$ thesis, Utrecht University, the Netherlands. Geologica Ultraiectina, 146, available from the Faculty of Geosciences and as Open Source document through NARCIS, http://dspace.library.uu.nl/handle $1874 / 274734$

*Zegers, T.E. \& Van Keken, P.E. 2001. Middle Archean continent formation by crustal delamination. Geology, 29, 1083-1086.

*Zegers, T.E., White, S.H., De Keijzer, M. \& Dirks, P. 1996. Extensional structures during the deposition of the $3460 \mathrm{Ma}$ Warrawoona Group in the eastern Pilbara Craton, Western Australia. Precambrian Research, 80, 89-105.

*Zegers, T.E., De Wit, M.J., Dann, J. \& White, S.H. 1998. Vaalbara, Earth's oldest assembled continent? A combined structural, geochronologic and paleomagnetic test. Terra Nova, 10, 250-259

*Zegers, T.E., Barley, M.E., Groves, D.I., McNaughton, N.J. \& White, S.H 2002. Oldest gold: deformation and hydrothermal alteration in the early Archean shear-zone hosted Bamboo Creek Deposit, Pilbara, Western Australia. Economic Geology, 97, 757-773. 